\title{
Pathways to Lasting Cross-Sector Social Collaboration: A Configurational Study
}

\author{
Christiana Weber $^{1} \oplus \cdot$ Helen Haugh $^{2} \cdot$ Markus Göbel $^{3} \cdot$ Hannes Leonardy $^{1}$
}

Received: 3 May 2019 / Accepted: 17 December 2020 / Published online: 7 February 2021

(c) The Author(s) 2021

\begin{abstract}
Cross-sector social collaborations are increasingly recognised as valuable inter-organizational arrangements that seek to combine the commercial capabilities of private sector companies with the deep knowledge of social and environmental issues enrooted in social sector organizations. In this paper we empirically examine the configurations of conditions that lead to lasting cross-sector social collaboration. Situating our enquiry in Schütz's theory of life-worlds and the reciprocity literature, we employ fuzzy-set qualitative comparative analysis (fsQCA) to analyse data gathered from 60 partners in 30 cross-sector social collaborations. We find two distinct types of configurational pathways leading to lasting cross-sector social collaboration which we label reciprocal economic exchange based on direct reciprocity, and reciprocal social exchange based on generalised reciprocity. The pathways vary in terms of the delivery of expected and unexpected resources and benefits. We introduce the concept of double relationality to explain the interdependence of structure and action in lasting cross sector social collaboration.
\end{abstract}

Keywords Cross-sector social collaboration $\cdot$ Life-world $\cdot$ QCA $\cdot$ Reciprocity $\cdot$ Social enterprise

\section{Introduction}

Cross-sector social collaborations bring together organizations from sectors with divergent logics and are central to understanding how organizations guided by different backgrounds, ethical values and beliefs can work together (Berger et al. 2004; Selsky and Parker 2005, 2010; Di Domenico et al. 2009; Austin and Seitanidi 2012a, b; Clarke and Crane 2018; van Tulder and Keen 2018). Collaborations between

Christiana Weber

christiana.weber@ufo.uni-hannover.de

Helen Haugh

h.haugh@jbs.cam.ac.uk

Markus Göbel

markus.goebel@hsu-hh.de

Hannes Leonardy

hannes.leonardy@ufo.uni-hannover.de

1 Institute of Management and Organization, Leibniz University Hanover, 30167 Hanover, Germany

2 Judge Business School, University of Cambridge, Cambridge CB2 1AG, UK

3 Department of Management and Economics, Helmut Schmidt University, 22043 Hamburg, Germany corporations and social enterprises (SEs) have attracted special attention from business ethics scholars because although both organization types generate income from trading, they differ in relation to sectoral values and practices (Googins and Rochlin 2000; Rivera-Santos and Rufin 2010; Selsky and Parker 2010; Sakarya et al. 2012; Ashraf et al. 2017; van Tulder and Keen 2018). Despite, or perhaps because of, the different sector logics (O'Mahony and Bechky 2008; Vurro et al. 2010), partners are argued to gain economically, socially and culturally from cross-sector collaborating (Austin and Seitanidi 2012a; Hahn and Pinkse 2014; Parmigiani and Rivera-Santos 2011; Weber et al. 2017). Fundamental to a dyadic cross-sector social collaboration that endures, is a satisfactory exchange relationship between partners (Kinge 2014). Thus, for the potential of cross-sector social collaborations to be realized, their inherent antithetical forces need to be overcome (Di Domenico et al. 2009; Weber et al. 2017).

Previous research has found a wide range of variables that influence cross-sector social collaborations, such as, shared interests, access to resources, managerial complexity (Austin 2000), trust and value co-creation (Austin and Seitanidi 2012a). Berger et al. (2004) highlight the importance of inter-organizational fit and structural alignment of 
missions, resources, management and culture to avoid partner misunderstandings and disappointments. Di Domenico et al. (2009) explicitly anticipate the tensions associated with competing practices and priorities intrinsic to partners' differing goals, governance and accountability structures and processes and theorize that a lasting cross-sector social collaboration rests on congruence between the priorities, practices and processes of both partners. Although prior studies shed light on the variables that influence cross-sector collaborations, they are summative and fall short of elucidating the extent to which combinations of different structure and action variables lead to a lasting cross-sector social collaboration.

We investigate the different pathways to lasting cross-sector social collaborations by employing Schütz's (1967) lifeworld theory. A life-world is understood as a clearly defined structure of interaction, communication, system of knowledge and relevance, that is, the institutionalized and unquestioned patterns of meaning that derive from experience of the world (Schütz 1967). Drawing on Schütz's theorization of life-world congruence, we review the extant collaboration literature and derive five conditions that influence a lasting cross-sector social collaboration, namely, congruence of goals, governance structures, administrative processes, accountability processes and exchange modalities. We then examine the extent to which different configurations of these conditions lead to lasting cross-sector social collaborations. We employ a set theoretic approach to analyse proprietary dyadic data gathered from both partners in 30 corporateSE collaborations. The Fuzzy Set Qualitative Comparative Analysis (fsQCA) method isolates the effects of different combinations of conditions on an outcome measure and thus recognizes equifinality - that there might be several pathways to reach the same outcome.

With this study we respond to calls for more empirical dyadic investigations of inter-organizational relationships (Provan and Milward 2001; Provan et al. 2007) and make three contributions. First, we extend the cross-sector social collaboration literature (e.g., Austin and Seitanidi 2012a, b; Seitanidi and Crane 2014; Lioukas and Reuer 2015). While prior research has predominantly investigated the influence of either structure or action on cross-sector collaboration (Rueede and Kreutzer 2015; Weidner et al. 2016) and thereby assumed or presumed monocausality, we derive the concept of double relationality to explain the co-presence of structure and action in four set-theoretic configurations that lead to lasting cross-sector social collaborations. Second, by using micro level fsQCA analysis (Ragin 2008; Fiss 2011; Schneider and Wagemann 2012), to identify different exchange modalities in such collaborations, we theorize relational processes of reciprocal economic exchange and reciprocal social exchange as well as the role of unconditional giving (Sahlins 1972) and the receipt of unexpected resources. Finally, our dyadic approach and empirical evidence of the significance of receiving unexpected resources allows us to enhance the reciprocity literature by shedding light on the presence of moral-oriented and relational reciprocity (Emirbayer 1997; Göbel et al. 2013) in lasting crosssector social collaborations.

The paper is laid out as follows. To begin, we review the literature on cross-sector social collaboration. Building on core concepts from two research traditions, the life-world (Schütz 1967) and reciprocity theory (Sahlins 1972), we derive five conditions for lasting corporate-SE collaborations. In the methodology we explain QCA and our set-theoretic approach. We next employ fsQCA to analyze dyadic data from corporate-SE collaborations. The results are then reported, and we use the literature on cross-sector collaboration, life-worlds and reciprocity to examine the plausibility of our findings. Our contributions to theory are explained, and the paper concludes with suggestions for future research.

\section{Conceptual Framework}

\section{Cross-Sector Social Collaboration}

Cross-sector social collaborations are increasingly perceived to be integral to responding to social, environmental and business ethics problems resulting from organizational and market failures, such as unemployment, homelessness, waste management and climate change (van Tulder and Keen 2018). For the purpose of this paper, we define a cross-sector social collaboration as a partnership between a corporation and a SE that is established to achieve common goals that explicitly address social and environmental problems and strive for social value creation (Austin 2000; Berger et al. 2004; Selsky and Parker 2005; Parmigiani and Rivera-Santos 2011; Seitanidi and Crane 2014; Clarke and Crane 2018). Social enterprises are defined as organizations that trade to address areas of social market-failure (Nicholls and Huybrechts 2016). Whereas the creation of social value is the primary objective of SEs, the generation of economic value can be a means to end, albeit never an end in itself (Felicio et al. 2013). One strategy to maximize social value is to engage in cross-sector social collaboration (Le Ber and Branzei 2010a, b).

A satisfactory exchange relationship between the SE and the corporation is fundamental to a lasting cross-sector social collaboration (Kinge 2014). Relationship satisfaction, in turn, describes the extent to which both partners are content with the material and relational outcomes and perceive sustaining the collaboration to be worthwhile (Kinge 2014). Examples of renowned and endured corporate-SE collaborations include Timberland-City Year (Austin 2000) and Danone-Grameen (Yunus et al. 2010; Murphy et al. 2012). 
Embedded in the different sectors, the partners typically approach the cross-sector social collaboration with differing goals, ownership structures, administrative processes and cultures (Fiol and O'Connor 2002; Berger et al. 2004; Selsky and Parker 2005; Di Domenico et al. 2009; Le Ber and Branzei 2010b; Parmigiani and Rivera-Santos 2011; Austin and Seitanidi 2012a, b). Corporations focus mainly, but not exclusively, on economic value creation by targeting profitable markets (Le Ber and Branzei 2010b). While SEs share with corporations the pursuit of financial sustainability, they differ in that their strategies also pursue social and environmental goals (Battilana and Dorado 2010; Clarke and Crane 2018). Despite, or because of, the different sector logics inherent in cross-sector social collaborations (Vurro et al. 2010), the partners are argued to have the potential to gain economically, socially and environmentally from working together (Parmigiani and Rivera-Santos 2011; Austin and Seitanidi 2012a; Hahn and Pinkse 2014; Weber et al. 2017).

The outcomes from cross-sector social collaborations vary on several dimensions (Kivleniece and Quélin 2012) that may be specific to one partner or shared by partners (Weber et al. 2017). The exchange value that corporations bring to cross-sector social collaboration is predominantly their financial resources, commercial knowledge and market legitimacy (Di Domenico et al. 2009; Rein and Stott 2009; Sakarya et al. 2012; Lefroy and Tsarenko 2013; Le Pennec and Raufflet 2016; Shumate et al. 2018). In contrast, the exchange value of an SE is derived from local knowledge and expertise (Sakarya et al. 2012), community networks, social capital (Millar et al. 2004; Sakarya et al. 2012) and social legitimacy (Di Domenico et al. 2009; Schiller and Almog-Bar 2013). The different sector logics of the collaborating partners however, also mean that potential benefits are confronted by the tensions and antithetical forces inherent in cross-sector social collaboration. Such tensions need to be overcome, and differences reconciled, for lasting cross-sector social collaborations (Di Domenico et al. 2009; Austin 2010).

To shed light on the determinants of a lasting crosssector social collaboration, extant research has identified an increasing number of variables that influence the extent to which collaborating partners work together. For example, Austin (2000) proposed that a collaborative relationship is influenced by levels of partner engagement, mission importance, resource magnitude, activity scope, interaction, managerial complexity and strategic value. More recently, Austin and Seitanidi (2012a, b) increase the array of variables by adding resources, trust, internal change, value co-creation, innovation and external systems change. Berger et al. (2004) mention fit between mission, resources, management, workforce, target market, product, culture, timing and evaluation to be relevant for collaboration success; and Di Domenico et al. (2009) propose congruence of goals, governance and accountability structures and processes to impact on lasting cross-sector social collaborations. To identify the conditions that influence cross-sector social collaboration success, we systematically analysed and categorized previous studies (Table 6 in Appendix).

From our review we distilled two core themes. First, the need for congruence or alignment between partner organizations, such as between missions, goals (Austin 2000; Googins and Rochlin 2000; Plowman et al. 2007; Rein and Stott 2009; Seitanidi and Crane 2009; Seitanidi et al. 2010; Nelson and Zadek 2011; Cloutier and Langley 2017), structures (e.g., Le Ber and Branzei 2010b) and processes (e.g., Austin et al. 2007; Austin 2010). The second core theme deals with resource exchange, either the content of what is exchanged (e.g., Austin and Seitanidi 2012a; Weber et al. 2017; Shumate et al. 2018) or the exchange processes involved, namely, the different modes of give and take (e.g., Austin 2010; Kivleniece and Quelin 2012) and the partners' expectations associated with the respective exchange modes (Austin et al. 2007; Le Ber and Branzei 2010b; Austin and Seitanidi 2012a, b). To theorize how the array of variables influence lasting cross-sector social collaborations and in order to capture both interpersonal as well as organizational level of analysis, we turn to the sociological aspects of exchange relationships and integrate phenomenological theory (Schütz 1967) and economic anthropology (Sahlins 1972).

\section{Life-Worlds and Social Action}

A 'life-world' describes the unquestioned patterns of meaning, clearly defined structures of interaction and communication, systems of knowledge and structures of relevance that are derived from experience of being in the world (Berger and Luckmann 1967; Schütz 1967). The life-world stands for relief from the burden of the 'openness to the world' associated with limitless, rational human potential for action. Whereas there are many life-worlds, the body of knowledge of a specific life-world is organized in keeping with the respective systems of relevance (Luckmann and Luckmann 1979). Depending on the structures of relevance found in subsidiary knowledge systems, knowledge is either appropriated or dismissed as irrelevant. The resulting body of social knowledge is conveyed in the everyday life-world through objects such as typifications, routines, roles and institutions.

According to Schütz (1960), interpersonal communication represents a predominant part of social action yet is fundamentally problematic already within life-worlds. No matter how much one partner seeks to perceive things in the same way as his partner, "all genuine understanding by an observer remains grounded in the interlocutor's self-interpretation" (p. 123). Even if the objects of other life-worlds are known or recognizable, the self realizes that the same 
object means something different to another person. Alongside the basic difficulties associated with coordinating successful interpersonal communication and interaction (Schütz 1960), the respective knowledge and relevance systems specific to the different life-worlds, in our case corporate and SE life-worlds, are additional hurdles to be overcome.

To mark the distinctive perceptual positioning of actors in their respective life-worlds, Schütz (1967) uses the concepts of 'distance' and 'difference', according to which our study's collaborating partners stand at different distances from an object. To illustrate, a SE partner is likely to stand closer to (i.e., be more familiar with) prosocial giving than a corporate partner. Moreover, Schütz (1967) describes a difference between the biographical situations of the other and the self, a difference that is at the same time the foundation of the actors' respective relevance systems. The difference that thereby arises between the individualistic perspectives cannot be completely eradicated but only neutralized for specific interactional situations. To do so, a person adopts the general hypothesis of the reciprocity of perspectives (Schütz 1967) that rests on two idealizations. First, that the respective standpoints are exchangeable such that there is certainty that the partners would view and experience things from the same perspective, at the same distance and within the same range as if one partner were in the 'shoes of the other'. Moreover, each partner also expects the other to engage in the same idealization. The second idealization is that the respective relevance systems are congruent with each other.

The idealization of congruence between the relevance systems assumes that dissimilarity of biographical situations is irrelevant to the momentary intentions of each person attempting to communicate. If the partners simultaneously engage purposefully in this idealization, the resulting congruence of the relevance systems is not usually total in the everyday world, for that is impossible, but is sufficient for effective communication. In a similar manner Giddens (1991) highlights, "what makes a given response 'appropriate' or 'acceptable' necessitates a shared-but unproven and unprovable-framework of reality" (p. 36), As the respective relevance systems align, a congruent structure of sense-making and knowledge emerges that constitutes the sociocultural basis on which norm-oriented and purposive actions can be meaningfully interrelated. In summary, reciprocity of perspectives is a premise of successful reciprocal action. Such reciprocity of action is defined as "motivationally interrelated action" (Göbel et al. 2013, p. 35) and contributes to relationship satisfaction and collaborations that endure.

\section{Reciprocity and Exchange}

The reciprocity of action assumes different forms in economic anthropology. Sahlins (2004) distinguishes between a direct, or balanced reciprocity, and indirect, or generalized reciprocity. Direct reciprocity is typically present in dyadic relationships based on the exchange of like or equivalent goods and values. This type of exchange is described as "tit for tat" (Axelrod 1984, p. 27) in which the guiding rule is to cooperate once at the beginning of a relationship and to continue by reciprocating precisely in terms of how the partner responded previously - no more, no less. "The material side of the transaction is at least as critical as the social: there is more or less precise reckoning, as the things given must be covered within some short term. [...] The relations between people are disrupted by a failure to reciprocate within limited time and equivalence leeways" (Sahlins 2004, p. 148). Inter-organizational relationships may however, also result in generalized reciprocity (Sahlins 2004), or "univocal reciprocity" (Ekeh 1974, p. 48) in which the interacting partners do not expect direct or equal returns, "the requital thus may be very soon, but then again it may be never" (Sahlins 2004, p. 147). In generalized reciprocity the resource provider does not know whether, when or what s/he will receive such that "the expectation of the reciprocity is indefinite" (Sahlins 2004 , p. 147). Generalized reciprocity thus involves a broadened exchange system in which willingness to cooperate and exchange is also important yet manifest as a generalized norm to which all participants feel a degree of commitment to 'the other' in their actions (Gouldner 1960). The obligation to reciprocate thus does not necessarily exist between resource provider and resource taker but, rather through generalized exchange between members of the exchange system (Ekeh 1974). The risk for the individual actor remains limited to the extent that exchange cycles of generalized reciprocity facilitate indirect, and typically delayed, returns and outcomes. Notwithstanding the risk that a member may renege, negative reciprocity (Sahlins 1972), each resource provider is also a resource receiver, though sometimes in a different, yet equally one-sided, exchange relationship.

\section{Conditions Facilitating Lasting Cross-Sector Social Collaborations}

In this section we integrate the core themes of life-world congruence (structure) and reciprocity (action) and identify specific areas of congruence that reflect the respective underlying systems of meanings (Schütz 1967) as socio-cultural artefacts and expressions (Sahlins 1972). The result of this integration is a set of five conditions associated with crosssector social collaboration that inform our analysis (Fig. 1, Table 6 in Appendix).

Congruence in missions and goals is noted in much of the cross-sector social collaboration research (e.g., Austin 2000; Googins and Rochlin 2000; Seitanidi and Crane 2009; Cloutier and Langley 2017). From a phenomenological perspective, an organization's mission is a cultural artefact of the respective sociocultural systems of symbols, and the 
development of a sociocultural context of knowledge and meaning is the basic condition of every goal-oriented act (Reckwitz 2002). Congruence between actors' missions suggests that reciprocity of perspectives (Schütz 1967) has been achieved, which implies that a viable inter-organizational communication order is in place (Weber and Göbel 2006, 2010). In other words, the actors cannot strategically act with success in mind until they have come to a shared understanding of each other's identity, role, function and so forth, through mutual typifications and attributions of meaning. In that sense, the congruence in missions and goals is an expression of an intersubjective sociocultural context of meaning that paves the way to joint acquisition of material benefits through cooperative action. Drawing on Schütz's understanding of successful interaction and communication coordination, some evidence of partners' mission and goal congruence is an essential pre-condition to lasting crosssector social collaborations and is thus a selection criterion for our sample.

\section{Congruence of Structures and Actions}

A key tenet in neo-institutionalism is that every kind of organization is expected to act purposively, that is, in a manner that demonstrates a recognizable link between means and ends. When it comes to the reciprocity of perspectives, each cooperating partner is well aware of the sociocultural constraints (but also the potential gains) that the other's different perceptual positioning brings to his or her particular organizational field with its diverging institutional logics. This different positioning also conclusively introduces differences into each partner's organizational formalization (e.g., governance structures, administrative processes and accountability processes) and makes them seem intelligible, and hence legitimate, to their partners. For example, if partners attribute a minimum of purposive rationality to each other's systems of action, then partial differences between the administrative processes will not necessarily impinge on the durability of the cooperative relationship. On the contrary, it may be that the partners consciously entered into their partnership precisely because of such dissimilarities and the potential gains entailed, hence they are willing to accept divergence as something that generates added value. Willingness is present if the underlying symbolic systems are congruent (Schütz 1967). This congruence of symbolic systems may then give rise to different forms of reciprocity of action (Sahlins 1972) that are each characterized by either the presence or absence of congruence between partners' structural features. To summarize, we note that congruence in the following structural features is conducive to a lasting cross-sector social collaboration:

\section{Congruence in Governance Structures}

The organizational form adopted by a corporation, usually the limited company, differs from that of the typical SE, either registered as the trading arm of a charity, trust or cooperative. Each organizational form's governance structure
Fig. 1 Conceptual procedure for the derivation of conditions

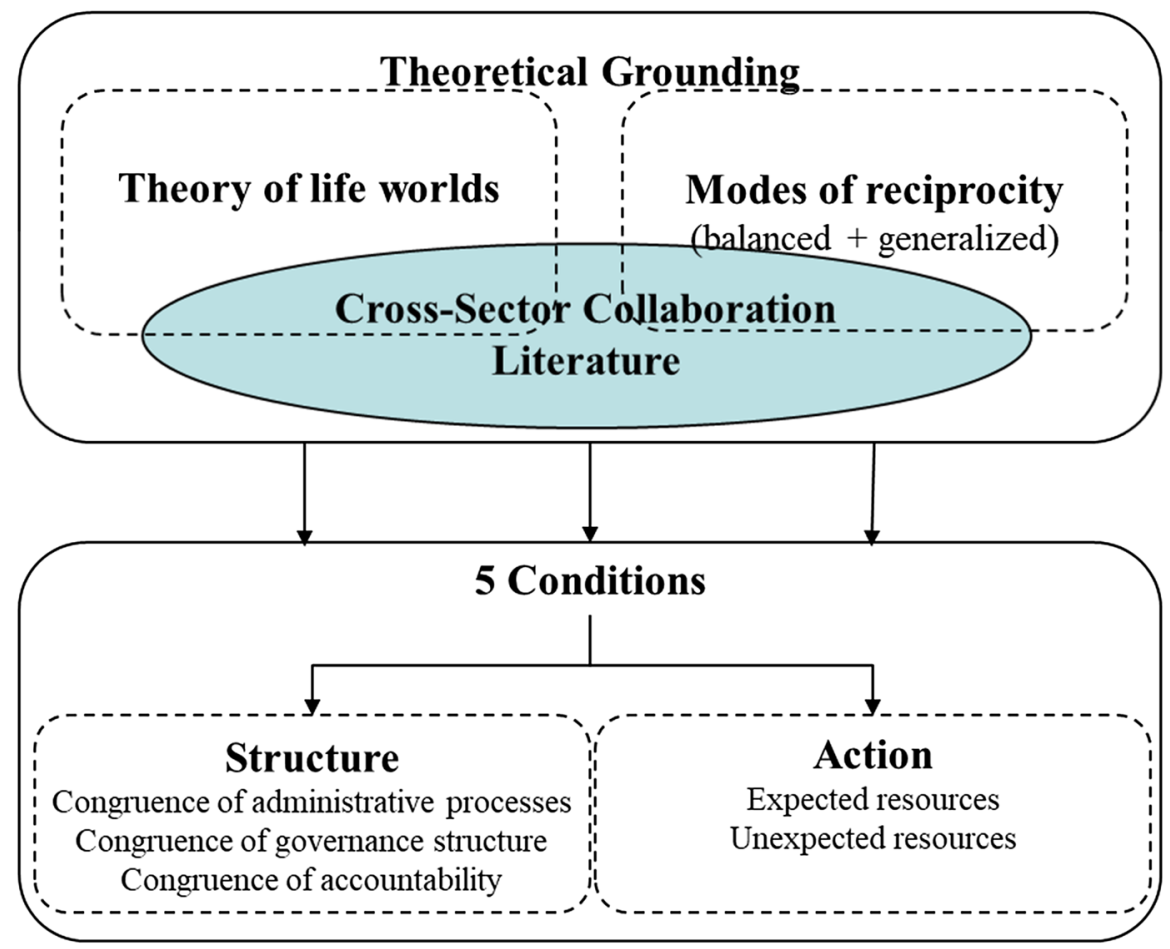


reflects their strategic priorities. If the different governance structures are mutually perceived to be congruent because the goals and missions (the overarching organizational context of meaning) are perceived to be congruent, then the governance structures reproduce that context of meaning at the action level (Weber and Göbel 2006, 2010). In turn, the partners acknowledge the legitimacy of each other's action and ensure requisite inter-connectibility. The levels of action and symbols are therefore regarded to be in relation to, not in isolation from, each other. The sense of inter-connectibility gives rise to an "aura of trust" (Meyer and Rowan 1977, p. 358 ) that lays the foundation for cooperation. In summary, despite, or because of, the different governance structures of corporations and SEs, perceived governance structure congruence is a necessary condition for a lasting cross-sector social collaboration (e.g., Di Domenico et al. 2009; Le Ber and Branzei 2010b; Rivera Santos and Rufin 2010; Kivleniece and Quélin 2012; Kinge 2014).

\section{Congruence in Administrative Processes}

Analogously, the internal operating practices of different organizational forms are also known to vary; the corporate profit motive keeps processes lean, whereas the multiple reporting obligations of a SE imposes layers of bureaucracy. In Schütz's terminology, identifying this alignment means reproducing organizationally superordinate contexts of meaning at the level of action, reciprocally granting legitimacy, and creating the necessary inter-connectibility. Finding alignment between the different administrative processes is thus a condition of a lasting cross-sector social collaboration (e.g., Di Domenico et al. 2009; Rivera-Santos and Rufin 2010; Kivleniece and Quélin 2012).

\section{Congruence in Accountability Processes}

Further, the extent to which different organizational forms require engagement with stakeholders varies. Corporations provide an annual financial report to shareholders and social and environmental reporting is, to some extent, optional. In contrast, a SE will typically supplement the financial report with a detailed account of social and environmental impact. From a phenomenological perspective, achieving congruent accountability processes means reproducing the cognitive order in the organizationally superordinate contexts of meaning at the level of action (see above). This inter-connectedness is important because it signals external stakeholders that the partnership follows rational mechanisms. As a consequence, external stakeholders ascribe or do not ascribe external legitimacy to the partnership. The conferral of external legitimacy, in turn, influences the partners' decisions to continue to collaborate. Congruence in accountability processes is thus a condition for a lasting cross-sector social collaboration (e.g., Di Domenico et al. 2009; Rein and Stott 2009; Austin 2010).

\section{Congruence in Resource Exchange Modes}

Prior research has examined the influence of different modes of give and take on lasting cross-sector social collaborations (Berger et al. 2004; Di Domenico et al. 2009; Austin 2010; Austin and Seitanidi 2012a, b; Kivleniece and Quelin 2012) and reciprocal expectations (Austin et al. 2007; Le Ber and Branzei 2010b; Austin and Seitanidi 2012a, b). Unfulfilled partner expectations are known to be a source of tension when inter-organizational relationships are at stake and associated with anger, frustration and even relationship termination (e.g., Weber and Weber 2011; Min 2017). Building on Sahlins (1972), we distinguish between balanced reciprocity, namely, outcomes that the partners requested and expect to achieve, this is expected resources and subsequent benefits, and generalized reciprocity, namely, outcomes that partners secured but that were not sought or expected when the collaboration was initiated, this is unexpected resources and subsequent benefits.

\section{Interdependencies of Conditions}

In the tradition of sociological and anthropological exchange theories (Malinowski 1922; Sahlins 1972; Ekeh 1974; LeviStrauss 1969; Mauss 1990), we acknowledge the dynamic interdependencies of intentionality and sociality in exchange systems. Extending Schütz's phenomenological perspective, Giddens (1984) describes how structures reciprocally enable and at the same time constrain actors' (inter-)action. By such highly recursive loops, different, idiosyncratic structureaction configurations emerge, "According to the notion of the duality of structure, the structural properties of social systems are both medium and outcome of the practices they recursively organize" (Giddens 1984, p. 25). Elaborating this view, Reckwitz (2002) explains that organizational structures exist only in the action taken by the actors. We therefore theorize that the conditions (structure and action elements) that lead to lasting cross-sector social collaborations function in an interactive, not additive manner. For example, congruence in missions and goals might influence the parties' administrative or accountability processes, which then have an effect on the governance structures.

While few studies to date have investigated the interplay between conditions, the recent study by Murphy et al. (2015) found that prior cross-sector collaboration experience moderated the effect of value creation alignment. Using exploratory factor analysis, they discovered that the presence of distinct factors "characterize the types of benefits sought by non-profit organizations and businesses engaged in cross-sector collaborations" (p. 145). Although 
their study describes the interaction effects, how bundles of conditions work together is not elucidated. Encouraged by Murphy et al.'s (2015) insights and given the development of techniques to examine interaction effects, we investigate the following questions: Which bundles of conditions lead to lasting cross-sector social collaborations and how do the conditions within those different bundles interact?

\section{Methodology}

To examine pathways to lasting cross-sector social collaborations, we followed the usual steps in QCA (i.e., Ragin 2008; Fiss 2011; Schneider and Wagemann 2012): collection of data; writing case descriptions; calibration of data; fsQCA (necessity and sufficiency) analyses of outcome and non-occurrence of the outcome; and review of results including identification of typical deviant cases (Schneider and Rohlfing 2013) and robustness tests.

We analyzed proprietary data gathered directly from both partners in corporate-SE collaborations. The data was gathered in four stages. The initial sample of SEs is drawn from the pool of applicants to the Schwab Foundation's Social Entrepreneurship Award (between 2005 and 2012), noting that success in securing an award was not a precondition of completing the survey. In the first stage $(t=1), 2245$ SEs were invited to complete a survey that investigated the type and extent of their involvement in collaborations. We asked about the nature of the relationship (lasting at that point in time for at least one year) with their most important partners. To facilitate data collection and analysis, we used either binary or Likert scales to formulate the survey questions. We further asked for permission for those most important partners to be contacted by the research team. 263 organizations fully completed the survey (response rate: $11.7 \%$ ) (see supplement). Organizations from our sample that did not match with our definition of social enterprise, e.g., charitable organisations, were excluded. Our final sample therefore included 199 SEs (response rate 8.9\%), reporting on 260 key partners. Following prior QCA research strategy (Fiss 2011), the surveys were administered online.

In stage two, (12 months later, $t=2)$ we approached the respective 260 partners and posed to them the same questions concerning their cross-sector social collaboration. Due to missing or incorrect partners' contact details, we reached 232 partner organizations. We received responses from 121 of those partners (response rate 52.6\%); 32 of the 121 responses were corporations and were thus included in our analysis. In stage three (12 months after stage two and 24 months after stage one, $t=3$ ) we again contacted both the SE and the corporate partner to gather further information about the dynamics of their relationship that expands our knowledge from the surveys. This information was gathered directly in interviews with the original respondents. The interviews were recorded and transcribed. When recording was not possible, detailed notes were taken during the interviews and written up immediately after. Following Crilly et al. (2012), data were analysed independently by the first two authors as follows. The transcripts and secondary data were scrutinized and coded. Statements which referred to explicit aims of the CSSP at founding were coded as 'expected outcomes'. Outcomes that had materialized but had not been planned for were coded 'unexpected outcomes'. The transcripts and documents were searched for explanations for how expected outcomes had been created or why they had not materialized, and how unexpected outcomes emerged and were explained by the informants. The different explanations were coded. The authors then discussed their independent analyses and agreed the conditions and outcomes for the CSSPs. Following Langley (1999) we then created a narrative of each collaboration that portrays the major insights on relationship development over time. Moreover, each case study narrative focuses on the underlying mechanisms concerning goal alignment, and congruence between governance structures, administrative processes and accountability. The analysis was inductive and conducted manually to stay close to the data.

To strengthen our connection with the data from the surveys and interviews, we gathered further data from a thorough review of the participants' websites and materials available online (published, audio and visual material). The additional data was employed to further inform the calibration of the data for the QCA analysis. Since mission and goal alignment is not only key for lasting cross-sector social collaborations (e.g., Austin 2000; Googins and Rochlin 2000; Seitanidi and Crane 2009; Cloutier and Langley 2017) but, more importantly, a key precondition in Schütz's (1967) theory, we included only those collaborations in which both partners explicitly explained that they predominantly seek to create social value via the partnership. This procedure led us to drop two dyads $(n=30)$. Additionally, prior research has shown that organizations entering a cross-sector partnership usually expect to gain at least one benefit/resource from their collaborating partner. All 60 partners in the 30 cross-sector dyads met this condition (Table 1).

\section{Analytical Strategy}

To discover interaction effects between conditions, we employed a configurational method. QCA is a theory-driven data reduction technique (Ragin 1987, 2008) designed to identify the conditions associated with the outcome of interest in cases characterized by complex causality. The technique is epistemologically appropriate for investigating complex social reality in that causal multicollinearity and conjunctive plurality are acknowledged (Schneider and 
Table 1 Corporate-social enterprise collaborations

\begin{tabular}{|c|c|c|c|c|c|c|c|c|c|}
\hline \multicolumn{5}{|c|}{ Corporate partners } & \multicolumn{4}{|c|}{ Social enterprises } & \multirow{2}{*}{$\begin{array}{l}\text { Collabo- } \\
\text { ration } \\
\text { estab- } \\
\text { lished }\end{array}$} \\
\hline$\#$ & Estab & $F$ & $\begin{array}{l}\text { Main areas of } \\
\text { activity }\end{array}$ & Location of HQ & Estab & $\mathrm{F} / \mathrm{P} / \mathrm{V}$ & $\begin{array}{l}\text { Main areas of } \\
\text { activity }\end{array}$ & Location of HQ & \\
\hline 1 & 1886 & 26,000 & Health, technology & $\begin{array}{l}\text { Holzkirchen, Ger- } \\
\text { many }\end{array}$ & 1997 & $22 / 6 / 4$ & Health, education & Navi Mumbai, India & 2000 \\
\hline 2 & 1973 & 153 & $\begin{array}{l}\text { Environment, water } \\
\text { sanitation, tech- } \\
\text { nology }\end{array}$ & Oslo, Norway & 2009 & $0 / 0 / 280$ & Education & Vitória, Brasil & 2003 \\
\hline 3 & 2002 & 150 & $\begin{array}{l}\text { Rural development, } \\
\text { construction, }\end{array}$ & Londrina, Brasil & 1990 & $14 / 7 / 6$ & $\begin{array}{l}\text { Education, social } \\
\text { services }\end{array}$ & Londrina, Brasil & 1990 \\
\hline 4 & 1958 & 90 & Water sanitation & Minneapolis, USA & 2006 & $200 / 5 / 0$ & Health, environment & Pune, India & 2007 \\
\hline 5 & 1994 & 491 & $\begin{array}{l}\text { Environment, manu- } \\
\text { facutring }\end{array}$ & Zug, Switzerland & 1999 & $0 / 6 / 18$ & Health, environment & Silves, Brasil & 2006 \\
\hline 6 & 2002 & 180 & $\begin{array}{l}\text { Environment, water } \\
\text { and sanitation }\end{array}$ & São Paulo, Brasil & 1998 & $4 / 2 / 300$ & Health, environment & São Paulo, Brasil & 2009 \\
\hline 7 & 1981 & 500 & $\begin{array}{l}\text { Professional activi- } \\
\text { ties }\end{array}$ & $\begin{array}{l}\text { Zoetermeer, Neth- } \\
\text { erlands }\end{array}$ & 2007 & $105 / 0 / 0$ & Health & $\begin{array}{l}\text { Utrecht, Nether- } \\
\text { lands }\end{array}$ & 2009 \\
\hline 8 & 1995 & 60 & $\begin{array}{l}\text { Health, financial } \\
\text { activities }\end{array}$ & Bern, Switzerland & 2008 & $2 / 12 / 1$ & $\begin{array}{l}\text { Health, education, } \\
\text { social services }\end{array}$ & Aarau, Switzerland & 2009 \\
\hline 9 & 2003 & 4 & $\begin{array}{l}\text { Rural development, } \\
\text { technology, con- } \\
\text { struction }\end{array}$ & Tiel, Netherlands & 1991 & $37 / 69 / 167$ & $\begin{array}{l}\text { Environment, social } \\
\text { services }\end{array}$ & Rishikesh, India & 2007 \\
\hline 10 & 1955 & 1500 & Manufacturing, & Caracas, Venezuela & 2002 & $28 / 0 / 150$ & Education & Caracas, Venezuela & 2006 \\
\hline 11 & 2007 & 2 & $\begin{array}{l}\text { Environment, } \\
\text { communication, } \\
\text { media, }\end{array}$ & São Paulo, Brasil & 2003 & $4 / 2 / 2$ & $\begin{array}{l}\text { Environment, } \\
\text { education, social } \\
\text { services }\end{array}$ & Chapecó, Brasil & 2012 \\
\hline 12 & 1982 & $>100,000$ & $\begin{array}{l}\text { Fair trade, whole- } \\
\text { sale }\end{array}$ & Tokyo, Japan & 2009 & $28 / 3 / 4$ & $\begin{array}{l}\text { Environment, } \\
\text { education, social } \\
\text { services }\end{array}$ & $\begin{array}{l}\text { Cuauhtémoc, } \\
\text { Mexico }\end{array}$ & 2009 \\
\hline 13 & 1983 & 22 & $\begin{array}{l}\text { Environment, } \\
\text { education, social } \\
\text { services, health }\end{array}$ & Caracas, Venezuela & 2012 & $2 / 0 / 11$ & $\begin{array}{l}\text { Health, environ- } \\
\text { ment, education }\end{array}$ & Caracas, Venezuela & 2011 \\
\hline 14 & 1998 & 22 & $\begin{array}{l}\text { Health, environ- } \\
\text { ment, education, } \\
\text { social services }\end{array}$ & Pokhara, Nepal & 1999 & $11 / 20 / 15$ & $\begin{array}{l}\text { Health, environ- } \\
\text { ment, education }\end{array}$ & Pokhara, Nepal & 1996 \\
\hline 15 & 2000 & & $\begin{array}{l}\text { Health, environ- } \\
\text { ment, fair trade, } \\
\text { manufacturing }\end{array}$ & $\begin{array}{l}\text { Santiago de Chile, } \\
\text { Chile }\end{array}$ & 2007 & $0 / 0 / 2$ & $\begin{array}{l}\text { Environment, edu- } \\
\text { cation }\end{array}$ & Chile & 2007 \\
\hline 16 & 1982 & 20,000 & Construction & $\begin{array}{l}\text { Santiago de Chile, } \\
\text { Chile }\end{array}$ & 1991 & $8 / 43 / 100$ & Health, education & $\begin{array}{l}\text { Santiago de Chile, } \\
\text { Chile }\end{array}$ & 2003 \\
\hline 17 & 1962 & 8300 & $\begin{array}{l}\text { Other (transporta- } \\
\text { tion and logistics) }\end{array}$ & $\begin{array}{l}\text { Santiago de Chile, } \\
\text { Chile }\end{array}$ & 1987 & $80 / 6 / 10$ & Health, education & $\begin{array}{l}\text { Santiago de Chile, } \\
\text { Chile }\end{array}$ & 2007 \\
\hline 18 & 1953 & 80,400 & Manufacturing & $\begin{array}{l}\text { Rio de Janeiro, } \\
\text { Brasil }\end{array}$ & 1996 & $2 / 10 / 12$ & $\begin{array}{l}\text { Education, social } \\
\text { services }\end{array}$ & Campinas, Brasil & 2008 \\
\hline 19 & 1985 & 300 & Other & Pescadero, USA & 2004 & $22 / 4 / 2$ & $\begin{array}{l}\text { Health, environ- } \\
\text { ment, education }\end{array}$ & Zurich, Switzerland & 2007 \\
\hline 20 & 1980 & 2000 & $\begin{array}{l}\text { Technology, com- } \\
\text { munication, media }\end{array}$ & $\begin{array}{l}\text { Santiago de Chile, } \\
\text { Chile }\end{array}$ & 1987 & $80 / 6 / 10$ & Health, education & $\begin{array}{l}\text { Santiago de Chile, } \\
\text { Chile }\end{array}$ & 1997 \\
\hline 21 & 1978 & 2004 & Financial activities & Quito, Ecuador & 2002 & $11 / 44 / 1$ & $\begin{array}{l}\text { Environment, } \\
\text { education, social } \\
\text { services }\end{array}$ & Quito, Ecuador & 2008 \\
\hline 22 & 2012 & 8 & $\begin{array}{l}\text { Health, technology, } \\
\text { manufacturing }\end{array}$ & $\begin{array}{l}\text { Pickering, Ontario, } \\
\text { Canada }\end{array}$ & 1987 & $34 / 1 / 0$ & $\begin{array}{l}\text { Health, environ- } \\
\text { ment, education, } \\
\text { social services }\end{array}$ & Milan, Italy & 2008 \\
\hline 23 & 1951 & 266 & Financial activities & $\begin{array}{l}\text { London, Ontario, } \\
\text { Canada }\end{array}$ & 1982 & $40 / 30 / 30$ & Social services & Cleveland, USA & 2006 \\
\hline
\end{tabular}


Table 1 (continued)

\begin{tabular}{|c|c|c|c|c|c|c|c|c|c|}
\hline \multicolumn{5}{|c|}{ Corporate partners } & \multicolumn{4}{|c|}{ Social enterprises } & \multirow{2}{*}{$\begin{array}{l}\text { Collabo- } \\
\text { ration } \\
\text { estab- } \\
\text { lished }\end{array}$} \\
\hline \# & Estab $F$ & & $\begin{array}{l}\text { Main areas of } \\
\text { activity }\end{array}$ & Location of HQ & Estab & $\mathrm{F} / \mathrm{P} / \mathrm{V}$ & $\begin{array}{l}\text { Main areas of } \\
\text { activity }\end{array}$ & Location of HQ & \\
\hline 24 & 2006 & & $\begin{array}{l}\text { Fair trade, enter- } \\
\text { prise development }\end{array}$ & $\begin{array}{l}\text { Amsterdam, Neth- } \\
\text { erlands }\end{array}$ & 2007 & $2 / 2 / 0$ & Fair trade & Recife, Brasil & 2008 \\
\hline 25 & 2009 & & $\begin{array}{l}\text { Rural development } \\
\text { (farming) }\end{array}$ & Bahia, Brasil & 2006 & $10 / 0 / 0$ & $\begin{array}{l}\text { Environment, social } \\
\text { services }\end{array}$ & $\begin{array}{l}\text { Rio de Janeiro, } \\
\text { Brasil }\end{array}$ & 2009 \\
\hline 26 & 1988 & 50 & $\begin{array}{l}\text { Manufacturing, } \\
\text { construction }\end{array}$ & Zulte, Belgium & 1997 & $10 / 100 / 20$ & $\begin{array}{l}\text { Other (recycling } \\
\text { textiles) }\end{array}$ & Exincourt, France & 2010 \\
\hline 27 & 1986 & 18 & Education & Billund, Denmark & 2010 & $55 / 275 / 0$ & Education, rural & Karnataka, India & 2010 \\
\hline 28 & 2004 & 5 & $\begin{array}{l}\text { Education, enter- } \\
\text { prise development, } \\
\text { microfinance }\end{array}$ & $\begin{array}{l}\text { Venezuela (and } \\
\text { Spain) }\end{array}$ & 2012 & $1 / 3 / 30$ & $\begin{array}{l}\text { Environment, } \\
\text { education, social } \\
\text { services }\end{array}$ & Caracas, Venezuela & 2011 \\
\hline 29 & 2007 & & $\begin{array}{l}\text { Education, social } \\
\text { services, home- } \\
\text { lessness }\end{array}$ & Lyon, France & 2009 & $6 / 1 / 30$ & Social services & Paris, France & 2009 \\
\hline 30 & 1950 & 360 & $\begin{array}{l}\text { Environment, edu- } \\
\text { cation, health }\end{array}$ & New York, USA & 1995 & $12 / 3 / 1$ & Environment & $\begin{array}{l}\text { Cape Town, South } \\
\text { Africa }\end{array}$ & 2007 \\
\hline
\end{tabular}

$F / P / V$ fulltime employees/Part time employees/Volunteers

Wagemann 2012) and is particularly suitable for midsize samples ranging between 15 and 60 cases (Ragin 1987; Muñoz and Dimov 2015; Cui et al. 2017). The method is based on the assumptions that an outcome is rarely attributable to a single cause, that causes rarely operate in isolation and that outcomes might be influenced by context (Ragin 1987; Schneider and Wagemann 2012). QCA also rests on researchers' rich knowledge of individual cases in a study (Berg-Schlosser et al. 2009) for setting thresholds within the calibration of set-memberships. Our multi-source data collection method led us to employ the more advanced analytical technique of fuzzy-set QCA (fsQCA). For fsQCA, the data is to be calibrated by defining full-membership (1) and non-membership (0), as well as the cross-over point for each condition studied. We constructed a truth table based on this procedure and then minimized it by using the Quine-McCluskey algorithm (see Table 7 in Appendix).

\section{Measures and Set Calibration}

In this section, we explain the set of measures used in this study, the rationale and thresholds for calibration. In configurational research, calibration is essential as it enables systematic comparison, ensuring that the different measures conform to dependably known standards (Schneider and Wagemann 2012). Using theoretical knowledge or observed distribution of raw scores, two team members independently specified the score that would qualify a case for full membership in the sets of high satisfaction with cross-sector social collaboration, as well as in the set of each of the five conditions. Also, the score that would completely exclude the cases from each of the sets. This is done by using an estimation technique that transforms raw scores into set measures (Ragin 2008), rescaling the original measure into scores ranging from 0.0 to 1.0 . In the following we present our measures, providing also calibration rationale and thresholds for each of them. The calibration table with all 30 cross-sector social collaborations is presented in Table 2 .

\section{Outcome Measure}

Lasting cross-sector social collaboration was operationalized in a two-step process. Both partners were contacted between 12 and 24 months after the initial data collection to assess if the collaboration was ongoing and, if so, information was gathered concerning their level of satisfaction with and resources gained from the collaboration. All collaborations were still ongoing. The satisfaction data was recorded on a 5-point Likert scale. We were thus able to capture both whether the relationship endured and partners' satisfaction, yielding nuanced insights into the respective crosssector social collaborations. We proceeded in this manner because, in line with Weber et al. (2017), we reason that partners would not continue to collaborate over a lengthy period if they were not by and large satisfied with outcomes, that is, if the costs exceeded benefits, or if the gains were unsatisfactory.

To construct the outcome measure we followed configurational logic. We first summed the satisfaction values for both partners. The creation of a single dyadic score by summing 
Table 2 Calibrated values for conditions and outcome measure

\begin{tabular}{|c|c|c|c|c|c|c|}
\hline $\begin{array}{l}\text { Cross-sector social } \\
\text { collaboration }\end{array}$ & $\begin{array}{l}\text { Governance } \\
\text { structure }\end{array}$ & $\begin{array}{l}\text { Accountability processes } \\
\text { (social audit) }\end{array}$ & $\begin{array}{l}\text { Administrative } \\
\text { processes }\end{array}$ & Expected benefits & $\begin{array}{l}\text { Unexpected } \\
\text { benefits }\end{array}$ & Satisfaction \\
\hline 1 & 0 & 1 & 0.555 & 0.321 & 0.528 & 0.66 \\
\hline 2 & 1 & 1 & 0.777 & 0.685 & 0.509 & 1 \\
\hline 3 & 1 & 1 & 0.000 & 0.636 & 0.789 & 0.49 \\
\hline 4 & 0 & 1 & 0.666 & 0.855 & 0.644 & 1 \\
\hline 5 & 1 & 1 & 0.666 & 0.436 & 0.574 & 0.66 \\
\hline 6 & 1 & 1 & 0.555 & 0.447 & 0.731 & 1 \\
\hline 7 & 1 & 1 & 0.222 & 0.455 & 0.481 & 1 \\
\hline 8 & 1 & 0 & 0.889 & 0.418 & 0.644 & 0.66 \\
\hline 9 & 0 & 1 & 0.666 & 0.224 & 0.532 & 0.49 \\
\hline 10 & 1 & 0 & 0.777 & 0.527 & 0.657 & 1 \\
\hline 11 & 0 & 0 & 0.444 & 0.709 & 0.648 & 1 \\
\hline 12 & 0 & 1 & 0.777 & 0.673 & 0.778 & 1 \\
\hline 13 & 1 & 0 & 0.778 & 1.000 & 1.000 & 1 \\
\hline 14 & 0 & 0 & 0.889 & 0.615 & 0.435 & 1 \\
\hline 15 & 1 & 0 & 0.333 & 0.745 & 0.611 & 1 \\
\hline 16 & 1 & 0 & 0.777 & 0.467 & 0.481 & 1 \\
\hline 17 & 1 & 1 & 0.778 & 0.685 & 0.537 & 1 \\
\hline 18 & 0 & 1 & 0.555 & 0.527 & 0.537 & 1 \\
\hline 19 & 1 & 0 & 0.777 & 0.285 & 0.370 & 0.33 \\
\hline 20 & 1 & 1 & 0.444 & 0.236 & 0.409 & 0.33 \\
\hline 21 & 0 & 1 & 0.778 & 0.527 & 0.454 & 1 \\
\hline 22 & 1 & 0 & 1.000 & 0.434 & 0.000 & 0.33 \\
\hline 23 & 1 & 0 & 0.777 & 0.000 & 0.421 & 0.66 \\
\hline 24 & 1 & 0 & 0.555 & 0.891 & 0.648 & 0.83 \\
\hline 25 & 1 & 1 & 0.444 & 0.709 & 0.769 & 1 \\
\hline 26 & 1 & 1 & 0.777 & 0.467 & 0.583 & 0.66 \\
\hline 27 & 1 & 0 & 0.777 & 0.491 & 0.544 & 0.33 \\
\hline 28 & 0 & 0 & 0.555 & 0.509 & 0.593 & 0.49 \\
\hline 29 & 1 & 0 & 0.222 & 0.515 & 0.639 & 1 \\
\hline 30 & 1 & 1 & 0.111 & 0.424 & 0.677 & 1 \\
\hline
\end{tabular}

the observations is the most common technique for dyadic measurement (Kenny et al. 2006; Tambling et al. 2011). This procedure resulted in a scale from 2 to 10 . We observed a skewed distribution of raw scores which suggests a relatively high satisfaction of the respective partners. Since it was our research interest to investigate social enterprises and their most important corporation partners, it was somewhat expected that the variance in satisfaction would hover around relatively high satisfaction scores. In line with our research interest and to counterbalance this observed effect, we defined the set of interest as 'high satisfaction' and set our cut point for set membership accordingly high. We calibrated our outcome measure the following: We allocated a value of 1 for dyads with a sum of $10,0.83$ for dyads with a sum of $9,0.66$ for dyads with a sum of $8,0.49$ for dyads with a sum of 7, 0.33 for dyads with a sum of 6 . Values of 5 and lower were allocated 0 . By allocating a 0.49 for dyads with a sum of 7 we acknowledge the theoretically possible but in our sample absent case that one partner is extremely satisfied (5) while the other partner is somewhat unsatisfied (2) - a situation which could indicate that the dissatisfied partner might be ready to leave.

\section{Congruence in Governance Structures}

Governance structure congruence was operationalized by using a binary measure of the presence or absence of a board of directors for both the corporation and the SE partners. Since this is a dichotomous variable, full membership (1) was determined if both partners had adopted the same governance structure (either presence or absence of a board of directors). If the partners did not have the same governance structures, they were allocated a non-membership (0). 


\section{Congruence in Administrative Processes}

We operationalized administrative processes by assessing the amount of regulations, paperwork, administration and bureaucratic procedures reported by the corporation and the SE partners. Each item was scored on a 5-point Likert scale. The delta between the partners' responses for each measure was calculated. Using the observed distribution of aggregate scores as anchors (average regulations 1.13; average paperwork 1.1; average bureaucratic procedures 1.26 ), we then calibrated the following: For each measure, full membership (1) was accorded a delta of 0 . A delta of 1 was accorded a calibrated value of 0.66; a delta of 2, 0.33; and all values higher than 2, full non-membership (0). The values for each dyad were then averaged to produce the final value.

\section{Congruence in Accountability Processes}

The congruence in accountability processes was operationalized with a binary measure to indicate the extent of external auditing being conducted in each partner organization. Since this is a dichotomous variable, full-membership (1) was determined when congruent accountability processes were in place (either presence or absence of audited financial and social impact accounts). If the partners' accountability processes were not congruent, they were allocated a nonmembership (0).

\section{Congruence in Resource Exchange Modes}

To distinguish between the receipt of expected and unexpected resources, we first generated a list of expected benefits from the literature review: Knowledge, finance, competencies, additional capacity and other benefits or resources. We asked both partners to indicate, for each resource, whether they expected to gain them from the collaboration (1) or not (0). Later in the survey we asked the respondents to report for each resource the actual outcomes of their collaboration. This data was scored on a 5-point Likert scale for each resource. The distinction between expected and unexpected resources gained from the collaboration was operationalized by pairing the resources that each partner had initially expected or not expected to receive from the collaboration with the actual resources that they reported having received. For each category (expected and unexpected resources) we averaged all values indicating the extent to which partners received each resource, and then combined the average of both partners into one measure for each category. This step resulted in a value scale ranging from 2 to 10 .

Using the observed distribution of aggregate scores as anchors (average receipt of expected resources 6.77; average receipt of unexpected resources 6.17) and following previous research (Kenny et al. 2006; Tambling et al. 2011), we calibrated the following: For both conditions (receipt of expected and unexpected resources) we allocated full membership (1) to scores equal to 10 , full non-membership (0) to scores equal or lower to 3.5. The cross-over point was set at 6.75 .

\section{Analytical Procedure}

We followed the set-theoretic multi method research literature (Ragin 2008; Fiss 2011; Schneider and Wagemann 2012) and first tested whether any of the conditions were necessary. The necessity test did not yield any individual conditions (see Table 8 in Appendix) with a consistency score of at least 0.9 (Schneider and Wagemann 2012). Thus, all conditions were retained. We next constructed a truth table by using the QCA Package Version 3.6 in the R software (Dusa 2019). The truth table lists all logically possible combinations, the consistency for each combination and the number of cases conforming to each combination (Fiss 2011). We specified the consistency threshold to produce results with consistencies at the recommended level of 0.85 or higher (Fiss 2011) and used the QCA package in the $\mathrm{R}$ software to minimize the truth table and generate our solution. For the intermediate solution, we defined the presence of each condition as directional expectation.

\section{Results and Discussion}

\section{Configurational Solutions}

The configurations of causal conditions for a lasting crosssector social collaboration are presented in Table 3. Following Ragin and Fiss (2008): Black circles () indicate the presence of a condition; circled crosses (x), absence; large circles, core conditions; small circles, peripheral conditions; and blank spaces condition irrelevance for a certain configuration. In our solution the overall solution consistency was 0.96, which is considered very high. The overall solution coverage of the models was 0.69 . We next calculated the proportional reduction in inconsistency (PRI) (Schneider and Wagemann 2012). The lowest PRI value was 0.92 , which is considered high. The consistency scores demonstrated the presence of clear set-theoretic relationships. In this way we identify configurations of our causal conditions, rather than the conditions in isolation, for lasting cross-sector social collaborations. Moreover, we found support for equifinality in that 4 different configurations of causal conditions were associated with lasting cross-sector social collaborations. Two sensitivity tests were conducted: the frequency cut was raised to two cases per truth table row; and the row consistency altered in the range from 0.928 and 0.96 . The results remain substantively unaltered. 
Table 3 Configurations for the presence of the outcome

Configurations for high satisfaction-Intermediate Solution

$n=30$, consistency threshold $=0.96$; frequency threshold $=1$; $\mathrm{PRI}>0.94$

\begin{tabular}{|c|c|c|c|c|}
\hline & \multicolumn{4}{|c|}{ Solution } \\
\hline & \multicolumn{2}{|c|}{$\begin{array}{l}\text { Reciprocal } \\
\text { economic } \\
\text { exchange }\end{array}$} & \multicolumn{2}{|c|}{$\begin{array}{l}\text { Recipro- } \\
\text { cal social } \\
\text { exchange }\end{array}$} \\
\hline & 1 & 2 & 3 & 4 \\
\hline Congruence in governance structure & & & & $\bullet$ \\
\hline Congruence in administrative processes & $\bullet$ & & $\bullet$ & \\
\hline Congruence in accountability processes & & & 0 & 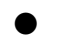 \\
\hline Receipt of expected resources & $\bullet$ & $\bullet$ & & \\
\hline Receipt of unexpected resources & & $\bullet$ & 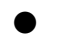 & $\bullet$ \\
\hline Consistency & 0.98 & 0.98 & 0.99 & 0.94 \\
\hline PRI & 0.97 & 0.97 & 0.98 & 0.92 \\
\hline Raw coverage & 0.52 & 0.58 & 0.31 & 0.24 \\
\hline Unique coverage & 0.04 & 0.05 & 0.03 & 0.02 \\
\hline Overall solution consistency & 0.96 & & & \\
\hline Overall PRI & 0.95 & & & \\
\hline Overall solution coverage & 0.69 & & & \\
\hline
\end{tabular}

Full circle indicate the presence of a condition and crossed circles the negation of a condition. Large circles indicate core conditions (form also part of the most parsimonious solution), small circles indicate peripheral conditions (form part of the intermediate solution)

The fsQCA results produce two sets of configurations. Models 1 and 2 are based on the causal condition of receiving expected resources. In Model 1, the causal conditions present are congruence between partner administrative processes and receiving expected resources. In Model 2 the presence of expected and unexpected resources is sufficient. Models 3 and 4 are based on the shared causal condition of receiving unexpected resources. They also include congruence between the partners' accountability processes and contain at least one other causal condition.

\section{Configurations and Expected Resources}

The causal condition of congruence in partners' governance structures was found only in conjunction with congruence in accountability processes and the receipt of unexpected resources (Model 4). The causal condition of congruence in partner's administrative processes was found in Model 1 in conjunction with the receipt of expected resources, and in Models 3 in conjunction with congruence in accountability processes and the receipt of unexpected resources. Congruence in accountability processes was a present causal condition in conjunction with the receipt of unexpected resources and congruent administrative processes (Model 3) or congruent governance structures (Model 4). The QCA technique thus showed that there are different configuration sets which lead to a lasting cross-sector social collaboration.

We had assumed that the receipt of expected resources from partners was a causal condition for a lasting crosssector social collaboration, yet this condition was present in Models 1 and 2 only. Moreover, it was present in combination with one other condition, either congruence in administrative processes (Model 1) or receipt of unexpected resources (Model 2). In Model 2, receiving expected and unexpected resources was sufficient without another condition. Summarising, Models 1 and 2 find that lasting crosssector social collaboration is achieved when both partners receive the resources they expected. We label this mode reciprocal economic exchange as it is based on a largely utilitarian and self-interested exchange which implies a 'tit for tat' mechanism in terms of timing and counter value. The collaboration between 3 Sisters Adventure Trekking company (3 Sisters) and the SE Empowering Women of Nepal (EWN) is a typical case of solution term 1 and illustrates the expected benefits pathway to lasting cross-sector social collaboration (Table 4).

\section{Illustrative Case Reciprocal Economic Exchange}

In 1993 three sisters opened a family restaurant and guest house in the tourist hub of Pkhara, Mount Annapurna, Nepal. While operating the guest house they discovered that many visiting female trekkers were uncomfortable with male trekking guides and porters. This opportunity led them to establish the 3 Sisters company to provide female trekking guide services to women. 3 Sisters employs 25 female guides and 40 female assistant guides and porters and has been widely recognized with awards from international travel and social change organizations. The SE EWN was established in 1999 to promote female education and empowerment in Nepal. Some recent EWN projects include female trekking guide training, health and sanitation awareness training, homestay program, microfinance to women self-help groups, grants to schools to buy books, science, technology and maths activities.

The cross-sector social collaboration between 3 Sisters and EWN leverages synergies between the two organizations. While EWN provides free empowerment training and trekking skills to girls aged $16+$ and prepares them for employment opportunities in the adventure tourism industry, 3 Sisters acts as potential employer for those educated girls, and with a connectable understanding of social responsibility towards those girls and women in general: "These two are totally different organizations ... but the two are working together, because 3 Sisters is always trying to develop women trekking guides, wanting to support women by women. The other side is how to get these women, and EWN provides training for the women," (3 Sisters). 
Table 4 Reciprocal economic exchange pathway

Corporate:3 Sisters Adventure Trekking (3 Sisters)

Expected resources and benefits

Goal alignment

Congruence in governance structures

Congruence in administrative processes

Congruence in accountability
The Collaboration Project (CP1)

In 1994, three sisters founded Nepal's first hiking guide services owned and operated exclusively by women and particularly for women. 3 Sisters has received many awards from international travel and social change organizations, and they have cultivated a unique niche in Nepal's adventure tourism industry, which is still largely dominated by men. 3 Sisters employs 25 female guides and 40 female assistant guides and porters

Mission: To promote adventure tourism and development in Nepal

Social enterprise: Empowering Women of Nepal (EWN) EWN was established in 1999 to promote female empowerment in Nepal. Projects include female trekking guide training, cleaning program, homestay program, microfinance to women self-help groups, grants to schools to buy books, etc Mission: To empower Nepalese females

$\mathrm{CP} 1$ provides free training to girls aged $16+$ to work in the adventure tourism industry and to raise their ambitions. Girls attend 6 months of free training to learn practical skills in English, Western culture, e.g., punctuality, not littering, washing hands etc., mountain climbing, rock climbing, guiding, cartography and first aid, personal health and hygiene, leadership, environmental sustainability and flora and fauna. Also training in equality, self-esteem and empowerment

Female empowerment

Female education and skills development

Raising female aspirations, attitudes and ambition

Female career progression

Changing societal attitudes towards women: Nepal has a patriarchal culture and women are treated one step up from an animal; only recently has it been acceptable for women to work outside the home doing more than nursing or teaching

Through the CP1 3 Sisters implements an essential component of its mission to empower women: The collaborators and EWN train women to be trekking guides

3 Sisters is registered as a for-profit company and EWN as a non-profit. Both organizations have independent boards of directors

Alignment of administrative procedures to facilitate training and recruitment of female trekking guides by 3 Sisters from EWN

Accounts audited by third party. In addition, both partners publicise the social impacts of the collaboration on their respective websites
The foundation of the shared mission is a reciprocal understanding of specific values and perceptions that establish a mutual context of meaning: "I believe that it is definitively important in any partnership that before you start working together both should have an idea of who the partner is and how the partner ticks" (EWN). To enable people to correctly interpret each other's perspectives, "generalized structures of expectations must constantly be taken into account" (Weber and Göbel 2006, p. 312). Accordingly, 3 Sisters report that as a result of such generalized structures of expectations, communication between them and EWN is facilitated: "Whatever we are doing, we communicate very well [...] even though we do not need to communicate much [...] it is very easy for us to communicate," (3 Sisters). This facilitated communication, in turn, is perceived by the partners as indicating a successful reciprocal adoption of perspectives in a Schützerian (1967) notion. In turn, the adoption of perspectives leads to a reinforced institutionalisation of the shared cognitive order.

The outcomes from the cross-sector social collaboration have been delivered, as expected, to both partners. More precisely, female empowerment, education and skills development to EWN and skilled and motivated female employees as trekking guides to 3 Sisters. These expected outcomes not only contribute to the long-term aspirations of both organisations, but also suggest a utilitarian perspective. It becomes apparent that, just as in a restricted exchange (in the notion of Sahlins 1996), the dyadic relationship is primarily endured by mutual interest in the exchange of complementary resources.

\section{Configurations and Unexpected Resources}

When Models 3 and 4 are considered together, receiving unexpected resources alone is insufficient for a lasting crosssector social collaboration. The configurations also need to include congruence in partners' accountability processes, and either congruence in administrative processes (Model 3 ) or governance structures (Model 4). In other words, Models 3 and 4 suggest that receiving expected resources is not necessary for a lasting cross-sector social collaboration. The results suggest that resources that go 'above and beyond' the expectations that are set when the relationship is first established may override failure to receive expected resources 
when other conditions are present and still lead to a lasting cross-sector collaboration. Models 3 and 4 are largely based on moral obligation between partners and therefore associated with generalized reciprocity. We label this exchange type reciprocal social exchange. Of special interest is the identification of a new variable, the pro-social provision of unexpected resources. To illustrate the unexpected resources pathway, we present the collaboration between the corporation Fresh Food Technology (FFT) and the SE Shri Jagdamba Samiti (SJS) from solution term 3 (Table 5).

\section{Illustrative Case Reciprocal Social Exchange}

FFT is a professional services company, based in the Netherlands, and specializes in the design and implementation of technological solutions into food value chains. The company provides on-site inspection, supervision, project management and monitoring services. Established in 1991, SJS supports economic, social and environmental development in the rural population in Indian Himalaya. The FFT and SJS collaboration, the Apple Project, is an initiative designed to empower small, rural farmers by improving apple production, storage, distribution and marketing. In addition to FFT and SJS, Apple Project stakeholders include the farmers and social investors.

A lasting cross-sector collaboration is foremost dependent on developing mutual understanding of each actor's perception of roles, goals and motives. While many of the partners in the Apple Project can refer to a homogeneous system of meaning and relevance based on their similar occupational experiences, the women members of the producer collective act in a life-world that socio-culturally strongly deviates from the life-world of other groups: "They're really excluded from the mainstream, the society and they're really locked up in the farms," (FFT). To obtain a mutual understanding of the other, namely to establish a reciprocity of perspectives, it was crucial for Apple Project partners to initially analyse and define institutionalized roles, motives and interests of the involved groups: "As a first step, those who initiated the Apple Project needed to understand what potential interest the farmers had to move up in the value chain [.... And, most of all, what is the willingness of individual farmers and farmer groups to participate in collective action by organizing themselves - and how can they be supported and guided in this?" (SJS). Put differently, the initial "lack of understanding of each other" (FFT), was played out in "struggles amongst some of these groups and there were distrust to be overcome and a lot of things," (FFT).

Gaining mutual understanding of the other's life-world in most cases results in a general cross-collaboration cognitive order (Weber and Göbel 2006, 2010). In the Apple Project this mutual understanding emerged from the abovementioned analysis of institutionalized roles, motives and interests of the involved groups. It subsequently became apparent in a "shared vison on social, political and economic objectives as prime driver to participate in this approach," (SJS). The new joint cognitive order constitutes the sociocultural background of both the action motives and action strategies of each actor. To illustrate, all actors, explicitly including the farmers, perceive and treat each other as equal business partners. "That's the first convention of us as a company [...] You don't treat them as a beneficiary, you don't treat them as a target group. They become simple equal business partners [...] to set up a viable business" (FFT). Over time, an Apple Project exchange system developed, characterised by fairness, reconciliation between interests and mutual obligations: "If you forget something and you hold up your hand and you feel awkward, but in this case they knew there was an obligation for repayment," (FFT). In this way the Apple Project has established a "win-win approach' that "look[s] for solutions that work for all partners, not just for the company," (SJS).

The Apple Project exchange system is structurally hedged by a joint board of directors and secured processually by shared practices and governance protocols: "To be in place for maximum transparency, control and reporting to all stakeholders, including the farmers," (SJS). This complex exchange system, described by Sahlins (1996) as a form of generalised reciprocity, includes multiple exchange partners and allows for the exchange of many goods and services the value of which is difficult to quantify. Examples of such goods and services might be the various forms of knowledge or the access to social capital (SJS). Ultimately the exchange via generalised reciprocity opens opportunities for unconditional giving and the subsequent unexpected receipt of resources.

In addition to receiving the expected resources, such as increasing farmers' income and autonomy, both FFT and SJS explained how the Apple Project had produced several unexpected outcomes (Table 5), of which we present one example in more detail. Traditionally Apple farming in the Indian Himalaya is a male occupation and any apples that do not meet the required quality standard, such as bruised and windfall fruit, cannot be used in the value chain but can be claimed by the women. The founder of SJS reported that: "When we had a meeting with farmer groups of men, the women were looking from a distance ... and one day, during our meeting, a few came over and asked, 'can you have any solutions for these bruised and left-over fruits?' And then we started to think. No one will restrict them to get these fruits, and then we started a juice factory," (SJS). Today, the apple juice factory is owned and managed by women from the region and the drinks products are sold in retail and hospitality outlets across India. Interestingly, the women's new juice business model is much more profitable than FFT's traditional business model. "Then we did a feasibility about 
Table 5 Reciprocal social exchange pathway

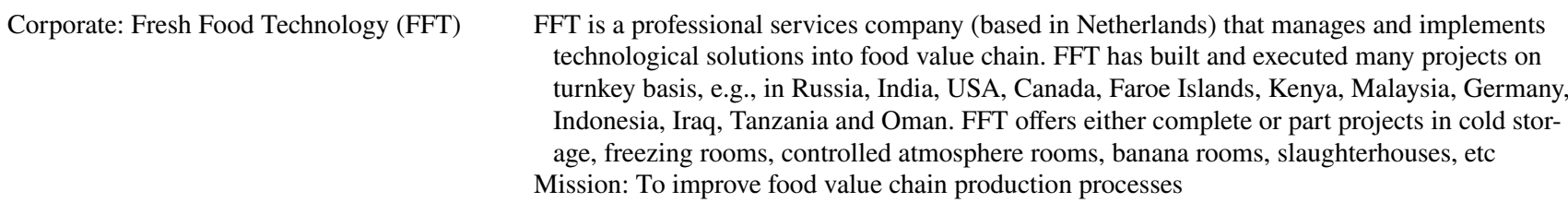

Social Enterprise: Shri Jagdamba Samiti (SJS) SJS aims to promote economic development of the rural population in the states of Uttarakhand and Himanchal Pradesh. Established in 1991, SJS started out as a voluntary group with the aim to foster sustainable development initiatives that use local resources. SJS strategy focuses on sustainable income generation projects

Mission: To support sustainable economic development

The Apple Project (CP2)

Expected resources and benefits

Unexpected resources and benefits

Goal alignment

Congruence in governance structures

Congruence in administrative processes

Congruence in accountability
CP2 aims to empower small, rural farmers through ownership and business model development. The model aims to help small farmers increasing their income by eliminating payments to middlemen and by business ownership

CP2 addressed disadvantages of traditional growing methods which were hampered by: isolated apple orchards in the foothills of the Himalayas; poor yield management; harvesting not at optimum times (picking season overlaps with rainy season); and product deterioration due to poor roads, and poor transportation infrastructure

Increase farmer income

Eliminate exploitative middlemen in value chain

Farmer empowerment

Although CP2 is aimed at farmers (males), female involvement in the apple juice business has helped to empower women

Farmer empowerment beyond economic gains, power comes from business ownership and not from membership of cultural class

Attraction of tourists to the region to see the apple ripening time and "Apple Day"

Using the slogan "Apple is the food of the Gods" apple tourism is also linked to the pilgrims that travel through the region

Greater awareness of ICT by installing ICT kiosks in different village centres

Raised awareness of resource management issues, e.g., climate change, renewable energy, environment and land and water management

New projects created to manage agriculture, land use, technology dissemination, water resources management (drinking water, sanitation)

Attracting additional social investors and influx of capital

Rapid development has been a feature of urban, not rural, economies however the CP2 brings development to rural communities

The aim of FFT is to sell technology to producers and manufacturers and the aim of SJS is.to scale sustainable economic development, in our case to improve apple farming production methods

The aim of SJS is to develop and implement a cooperative-based agricultural value chain in the apple farming and the aim of FFT is to build and sell controlled atmosphere storage and cold chain infrastructure

While FFT and SJS have independent boards of directors, FFT and SJS have established a joint company to jointly grade, sort, pack and sell the apples. The joint company is being gifted, over time, to the farmers

Alignment of processes and procedures. Integration of information and communication technology between FFT and SJS to establish controlled atmosphere storage facilities in the apple growing region

Financial and social accounts (i.e., SROI) audited by third party. In addition, both partners publicise the social impacts of the collaboration on their respective websites juice making and the most obvious one was the apple juice and the strange thing is that the whole business case of the juice making is much more attractive commercially than the long-term storage facility," (FFT). Summarizing the Apple project, we conclude that the producer collectives have a new product, the juice, to sell. Most importantly, the underprivileged women are socially empowered and their families are financially supported; SJS successfully implemented and governed the apple project, and 'over-accomplished' its mission due to additional women empowerment; the business partner (FFT) increased its reputation as a socially responsible organisation, and finally, the social investor "overreached" (SJS) its initial economic and social impact goals.

Reconnecting to the structure-action debate (Giddens 1984), the illustrative case studies elucidate how action is neither just a result of structure, nor does action stabilize 
the 'quasi-given' structure. Socio-cultural systems are, thus, according to Giddens (1991 p. 36) "simultaneously sturdy and fragile". The Apple Project in particular portrays how action can also change structure. At outset, the partners SJS and FFT collaborate to support male apple farmer business development. As the women in the apple farming communities become more knowledgeable about business development they seek advice from SJS about how to develop a business from the bruised fruit. SJS broaden their perspective from supporting the male farmers to include supporting business development by women in the apple farming communities. SJS approach FFT to support the apple juice business venture and in doing so FFT gains a deeper understanding of female empowerment. The recursiveness between structure and action demonstrates that in a relationship action and structure reciprocally stabilize each other (Fig. 2, Loop 1). Further, that in relational reciprocity the motivation for each partner to act is causally aligned with processes of mutual recognition, attribution and interpretation (Weber and Göbel 2010) (Fig. 2, Loop 2). In the course of such interactive processes, that 'double relationality', partners endeavour via the explained idealizations to take the perspective of the other (Schütz 1967) in order to facilitate mutual reality-building that is associated with congruence between partners' priorities and practices. Moreover, each partner's motivations to act also change, consciously or unconsciously, in the wake of the extent of adoption of the other's perspective. The motivations for action are thus not given beforehand but emerge through a recursive process of attribution. As illustrated in Fig. 2, the social-constructivist acts of mutually attributing and formulating motives (Loop 2) are rooted in the sociocultural symbolic structures (cognitive order) of the participating actors' life-worlds
(Loop 1). In the context of double relationality, these symbolic structures are continuously renewed through reciprocal processes of perception, attribution, and interpretation in the communicative behavior of the actors. During the individual acts of communication, namely a successful adoption of perspective, that is manifest in reciprocally compatible communication leads to changes in the symbolic structures of the corresponding life-worlds. In this way a cross-actor life-world with a largely commensurable structure of symbols may develop.

\section{Contributions}

Our study set out to empirically examine the configurations of causal conditions that lead to lasting cross-sector social collaborations and explain how the bundles of conditions interact. Using fsQCA to analyse proprietary data gathered from both partners engaged in cross-sector social collaborations, this paper joins a small group of empirical studies that investigate the antecedents of partnership level alliance performance (Provan et al. 2007; Weber et al. 2017). The analysis of 30 corporate - SE collaborations found four configurations that lead to lasting cross-sector social collaboration. Two configurations are largely based on reciprocal economic exchange and two further configurations largely depend on reciprocal social exchange. In this section we elaborate the contributions from our research.

\section{Contributions to Cross-sector Social Collaboration}

Our first contribution is to extend cross-sector social collaboration literature by theoretically developing and empirically

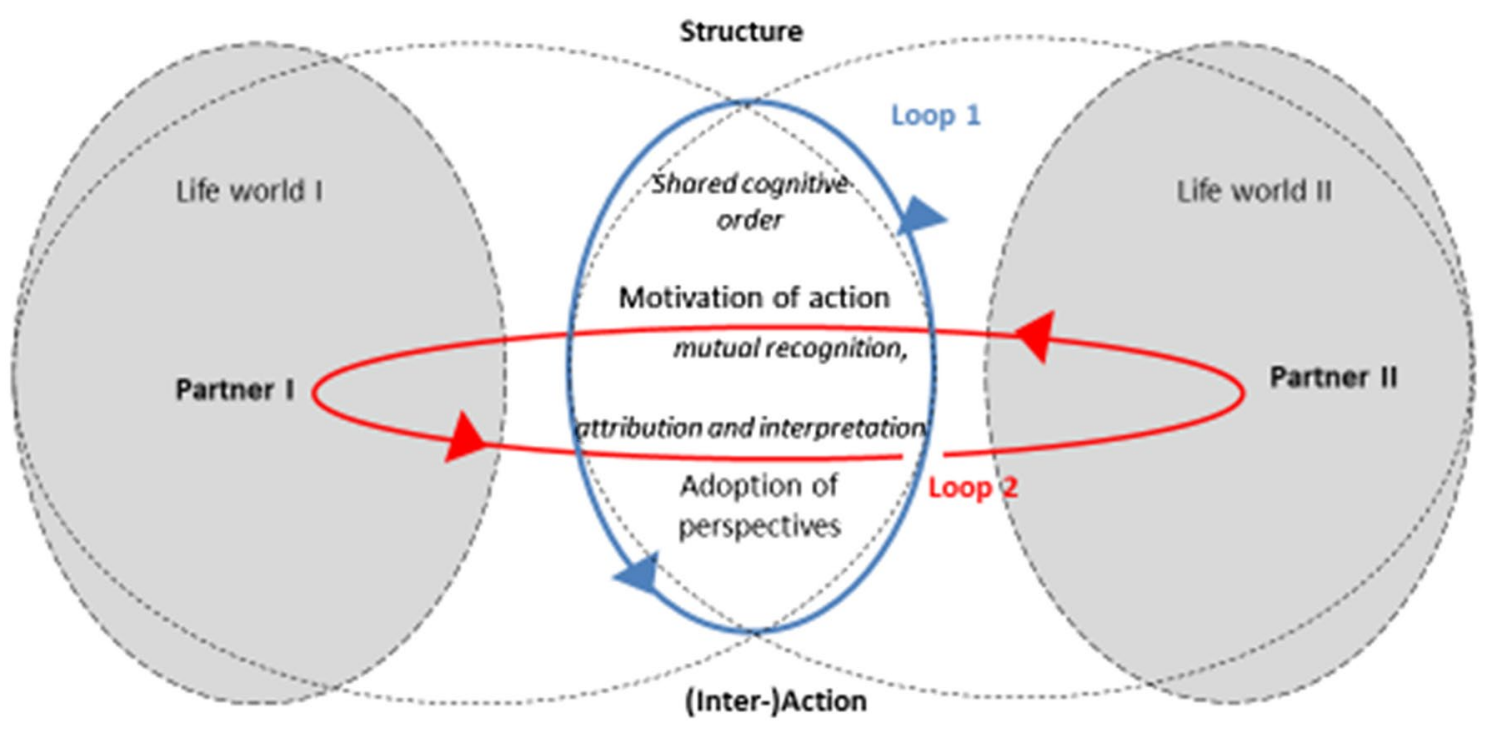

Fig. 2 Double relationality as a mechanism of mutual reality-building 
exploring how a lasting cross-sector social collaboration is achieved. Prior research has predominantly investigated the influence of either structure or action variables on crosssector social collaboration (Montgomery et al. 2012; Rueede and Kreutzer 2015; Weidner et al. 2016). By concentrating on one aspect, scholars have usually neglected the other and either assumed or presumed monocausality. Such approaches however, are ill-suited to cross-sector social collaboration research because they exclude possible interactions between the dimensions of structure and those of action. Grounded in Schütz $(1960,1967)$, our theoretical lens enabled us to incorporate his conceptual idea that structure and action are always interrelated and therefore cannot be observed in isolation from each other (see also Giddens 1984). Our finding concerning the inseparability of structure and action supports Koschmann et al. (2012) that cross-sector collaboration is "not merely an issue of structural arrangements" (p. 333). Showing that three (of four) configurations include both structural characteristics (governance and accountability) and some form of action (exchange of resources), empirically demonstrates the duality and inter-dependence of structure and action. By empirically finding and explaining the co-presence of structure and action in lasting crosssector social collaborations and illustrating the interaction between those elements, we extend theoretical explanations and empirical evidence of the conditions that enable cross-sector social collaborations to endure. Moreover, we complement this stream of literature with novel theoretical grounding.

Our second contribution to the cross-sector social collaboration literature is to carve out two different exchange modalities in such relationships. From our analysis we theorize the relational processes of reciprocal economic and social exchange and demonstrate the importance of differentiating between these two modalities. The findings also demonstrate the importance of distinguishing between expected and unexpected resources because a lasting cross-sector social collaboration can be achieved when partners receive either type of resource or both. By including the construct of unexpected resources in our analysis, we expand previous research that has typically focused only on the exchange of expected resources (e.g., Cropanzano and Mitchell 2005; Selsky and Parker 2005; Seitanidi 2007; Nelson and Zadek 2011). Identifying the causal condition of receiving unexpected resources enables us to theorize the role of unconditional giving in cross-sector social collaboration (Berger and Luckmann 1967; Schütz 1967; Sahlins 1972) and to introduce a new way of theoretically framing pro-social, unconditional giving.

Third, cross-sector collaboration research has adopted a predominantly neo-institutional framework in which structuralist elements are prevalent. Our action-oriented lens (adopted from Schütz 1967) introduces a novel theoretical approach to explaining cross-sector social collabo-ration. By showing the action-structure interdependence (Fig. 2, Loop 1), we reveal a new, and empowered type of actor for research on inter-organizational relationships. With this type of actor we take up sociological institutionalism's recent turn to a stronger orientation to actors and extend knowledge about dealing strategically with institutionalized exchange structures, for these exchange structures, which action has initiated and changed, lead in turn to new exchange systems. In this line of argument, we introduce the concept of double relationality to better explain the interdependence of actors' motivation of action and their socio-cultural setting.

\section{Contributions to Reciprocity Theory}

Our review of the literature noted that the few studies considering the influence of pro-social norms in inter-organizational relations have been dominated by utilitarian assumptions and a substantialist ontology concerning exchange relations (Blau 1964). Reciprocity has rarely been acknowledged from an ontological perspective as a fundamentally relational concept (Emirbayer 1997; Göbel et al. 2013). Our empirical evidence of the significance of receiving unexpected resources indicates the relevance of pro-social norms when setting up inter-organizational relationships and also supports the idea of a relational ontology of reciprocity. We show that a theoretical lens is fruitful "which abandons the traditional dualism between 'subject' and 'object', 'action' and 'structure' or 'body' and 'mind' in favour of a praxeological-because it is relational-understanding of reciprocal interaction processes and which considers in this context the action motivation but as a changing variable (not as a constant)" (Göbel et al. 2013, p. 12). Our illustrative case studies explain how actors' motivations for action emerge out of an own dynamic of reciprocal attribution of motives and interpretations of action. In our case a partner's motives for action do not develop until the attributes and particular motives for action of the other partner is known, and vice versa. This reciprocal attribution, however, necessarily draws on the symbolic, institutional (structural) level. Motives for action are thus not independent and fixed entities. Instead, 
they are first constituted by motive attributions and typifications that are then updated in the two parties' communicative action in a specific situation.

\section{Conclusion}

This study extends research on the interdependencies between conditions and their cumulative effect on interorganizational relations (Muñoz and Kibler 2015; Murphy et al. 2015; Ott et al. 2019). In addition, investigating the nature and outcomes of cross-sector social collaborations inherently required us to overcome the methodological challenges associated with gathering and analysing dyadic data. Our methodology enabled us to extend the important body of dyadic research to inter-organizational relationships in general and cross-sector social collaboration in particular. A dyadic approach to evaluating collaboration outcomes at the partnership level is "both reasonable and desirable" (Provan and Milward 2001, p. 422) as a way to "understand ... how collective outcomes might be generated" (Provan et al. 2007, p. 480).

While prior research has demonstrated that ethical values, specifically reciprocity, are an important aspect of social life in general (Gouldner 1960; Mauss 1990; Fehr and Gächter 2000), our analysis suggests that the importance of reciprocity also holds for lasting cross-sector social collaborations in particular. Deemed to be ethical because they create social value for society (Bull and Ridley-Duff 2019), ethicality has been viewed as a differentiating factor between SE and commercial organizations (Di Domenico et al. 2009). In crosssector social collaborations between SEs and corporations however, reciprocity is a shared ethical value in some lasting relationships. Moreover, the presence of reciprocal social exchange suggests that economic reciprocity is, at best, a partial explanation for some lasting cross-sector social collaborations.

To conclude, we identify three promising research themes that arise from our study. First, our research design employed a composite list of resources distilled from the literature and then compared resources expected and received.
The isolation of the importance of unexpected resources for lasting cross-sector social collaborations opens up opportunities to further examine the sources, characteristics and exchange of unexpected resources. Incorporating unexpected resources into further research would enable current management theory to include a new aspect of understanding, managing and developing inter-organizational relationships.

Second, the results concerning generalised reciprocity in lasting cross-sector social collaborations are an important new insight into how organizations may practically foster inter-organizational relationships. However, while the methodology adopted in the study gives first insights into the how of generalised reciprocity, further research could investigate why certain decisions are made, implemented or ignored. A qualitative study of both partners to examine the processes of generalised reciprocity in more depth would make a valuable contribution to understanding this phenomenon and the evaluative cognitive processes involved. Research might explore how unexpected resources are determined, sourced and evaluated. When and why do some organizations intentionally over-deliver? Research sites could be extended to multiple cross-sector social collaborations such as publicnonprofit partnerships (e.g. Suárez and Esparza 2017; Gaeta et al. in press) to assess the extent to which partners reciprocate within or across portfolios.

Third, fsQCA enabled us to identify configurations in lasting cross-sector social collabo-rations. However, set theory limits the number of variables that can be investigated together (Fiss 2011). Thus, our insights into the influence of multiple conditions of cross-sector social collaborations could be extended by examining other variables or by extending our model. Additionally, QCA could be employed to investigate the effects of multiple conditions in samesector collabo-rations and thereby contribute to theory to explain endogenous growth of the social economy.

\section{Appendix 1}

See Tables 6, 7 and 8 . 


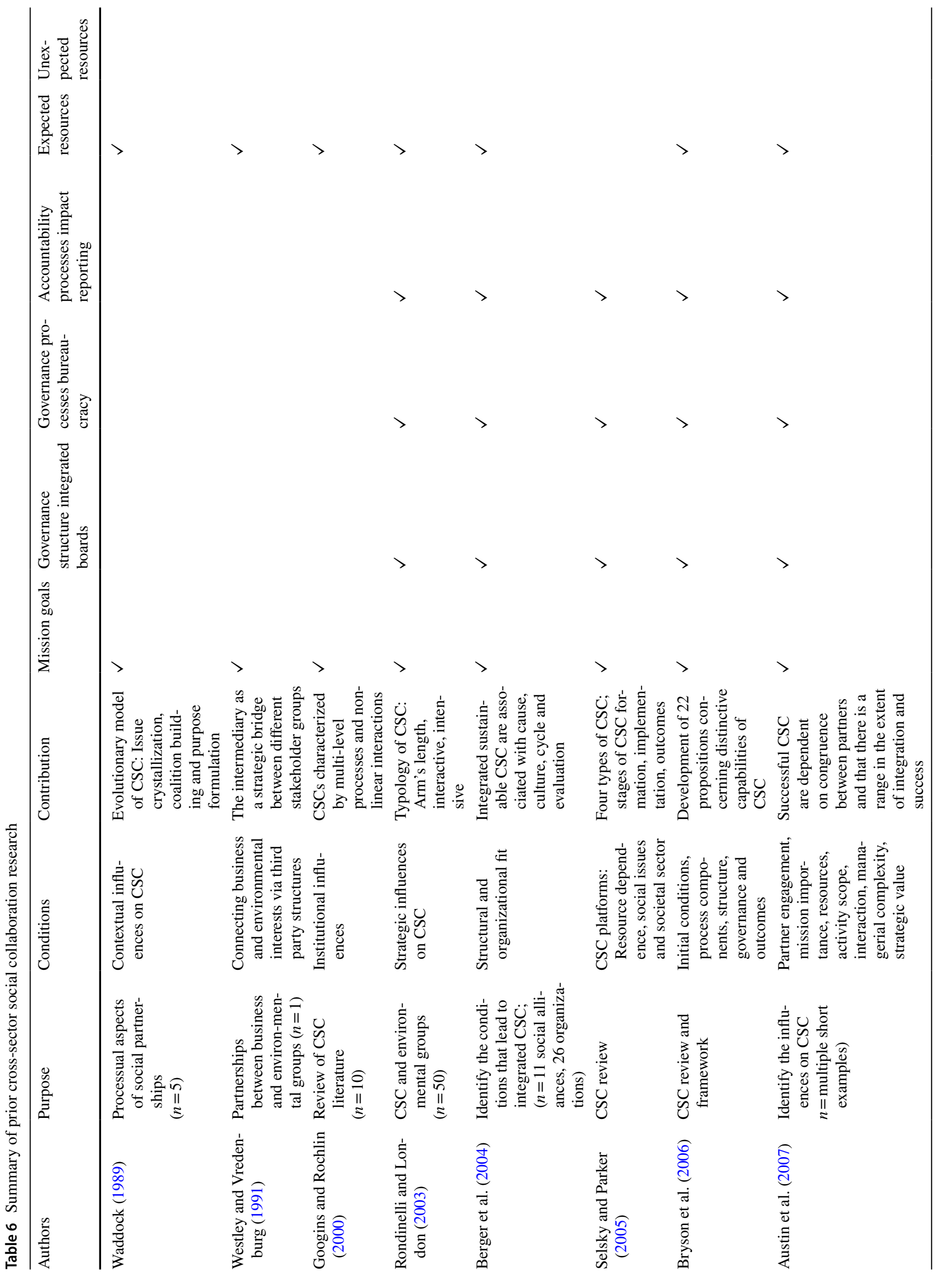




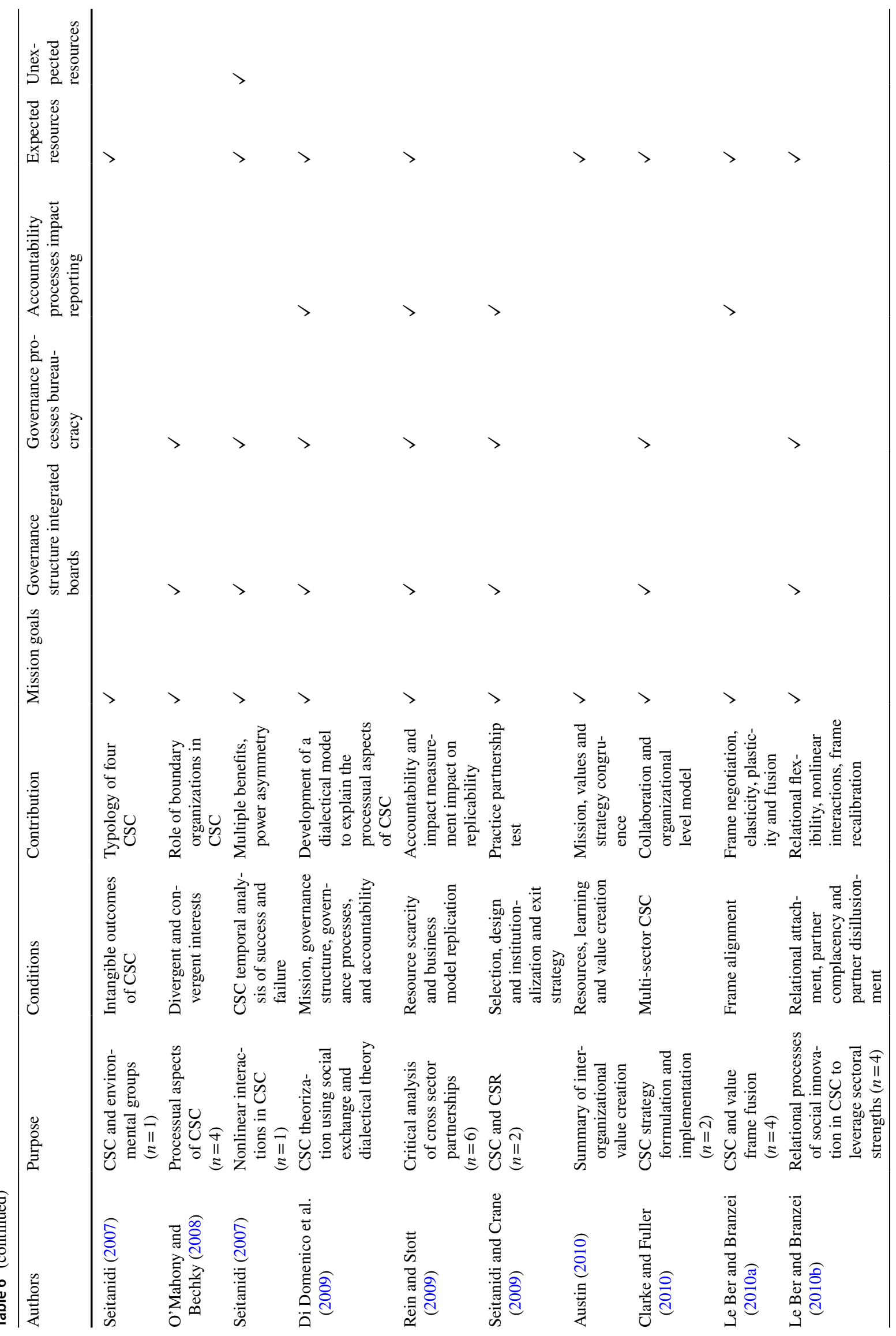




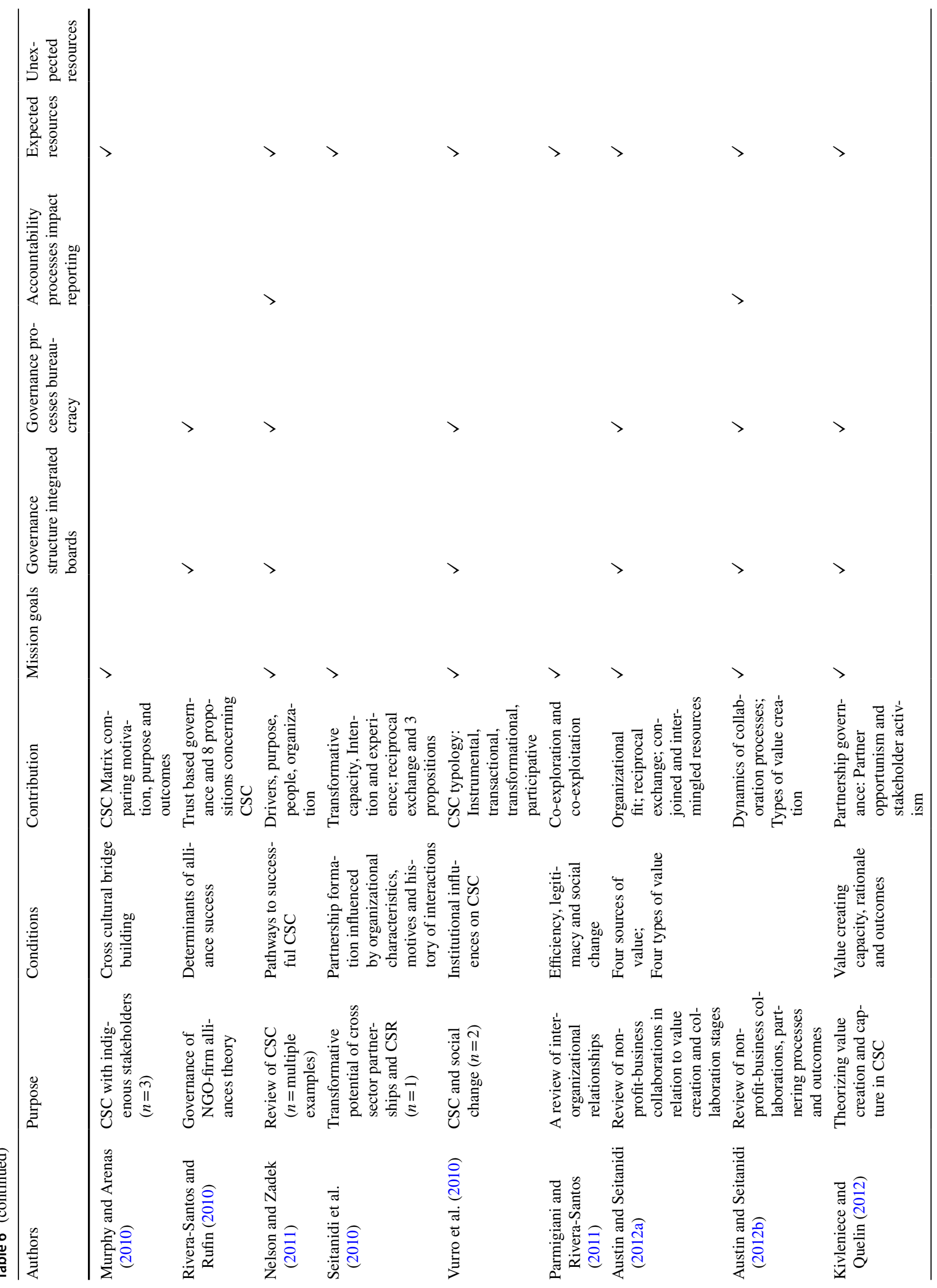




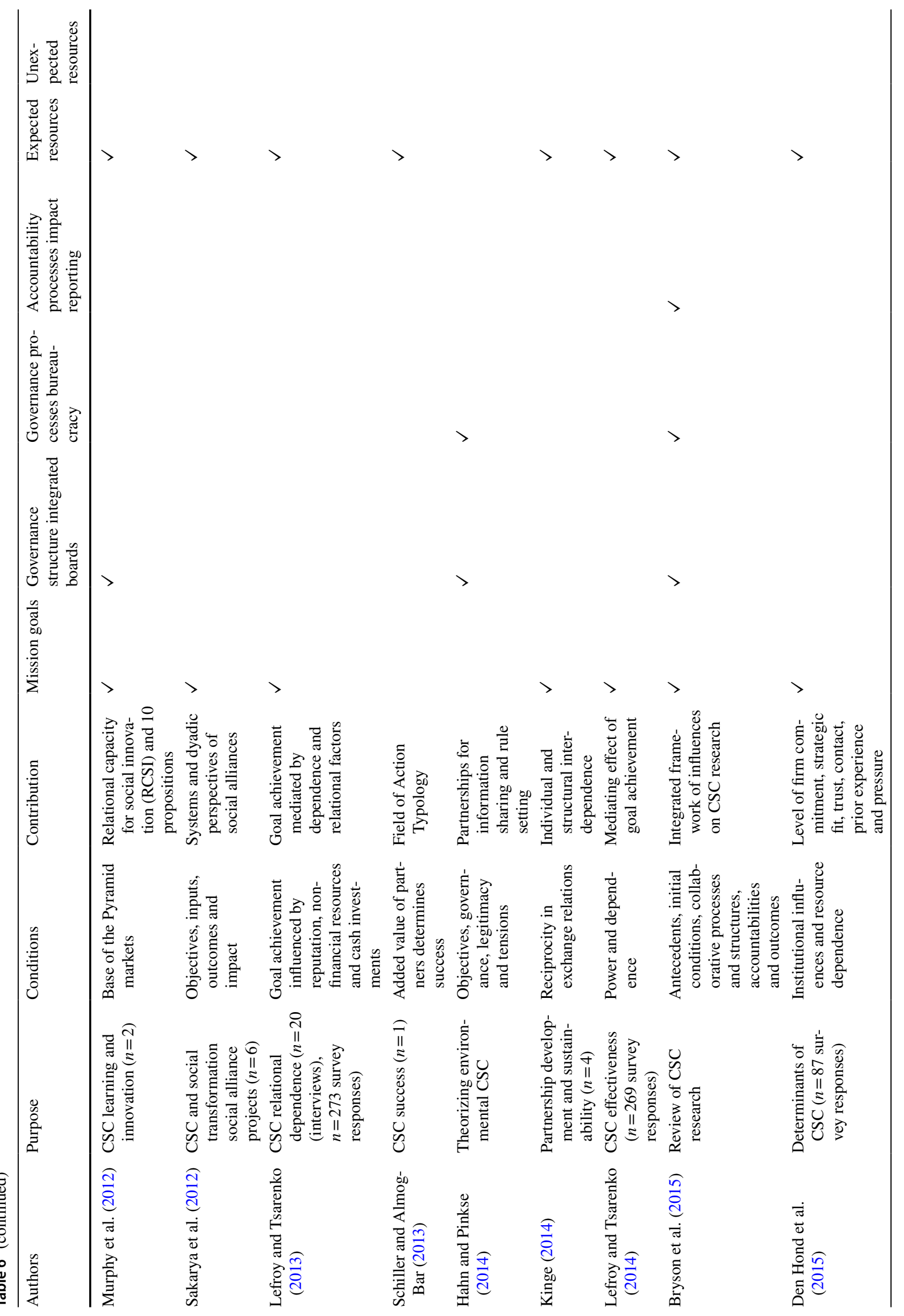




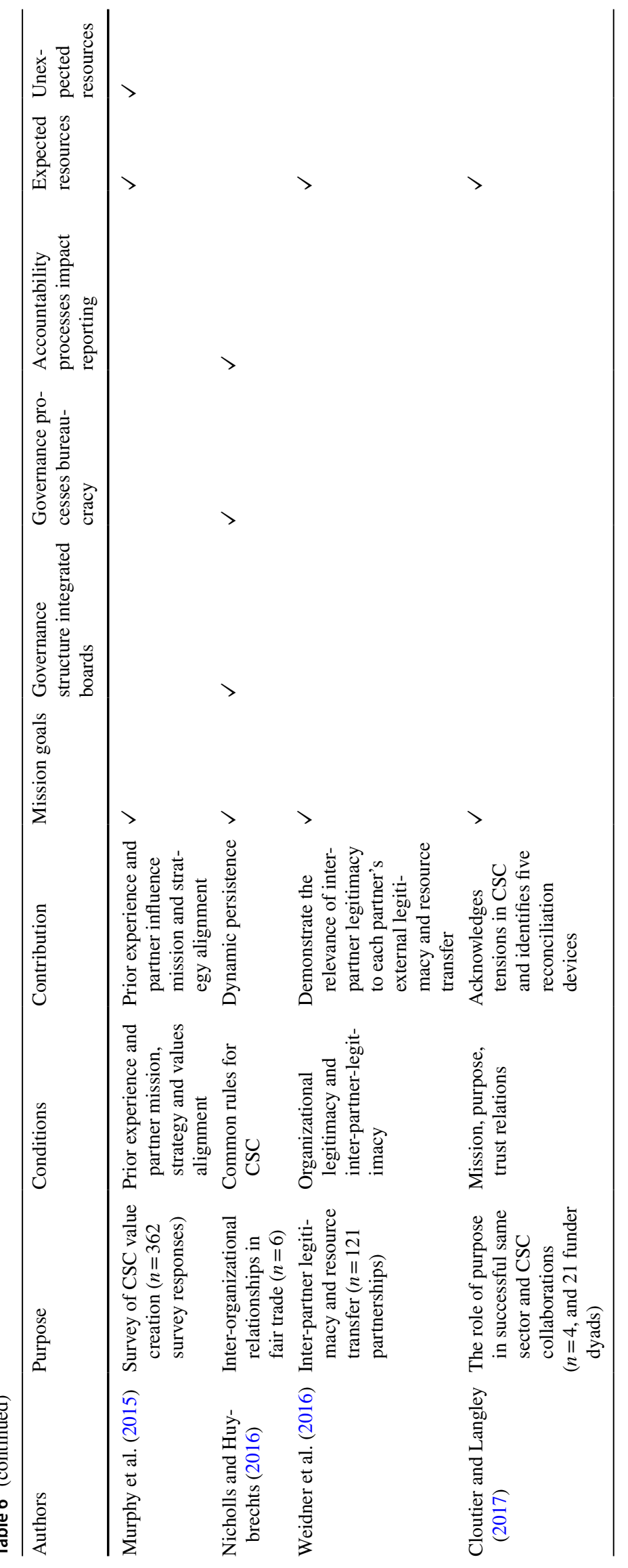


Table 7 Truth table for presence of the outcome

\begin{tabular}{|c|c|c|c|c|c|c|}
\hline Admin & Account & Govern & Expected & Unexpected & Consist & $n$ \\
\hline 1 & 1 & 0 & 1 & 1 & 1 & 3 \\
\hline 0 & 0 & 1 & 1 & 1 & 1 & 2 \\
\hline 1 & 1 & 1 & 1 & 1 & 1 & 2 \\
\hline 0 & 0 & 0 & 1 & 1 & 1 & 1 \\
\hline 1 & 0 & 0 & 1 & 0 & 1 & 1 \\
\hline 1 & 1 & 0 & 1 & 0 & 1 & 1 \\
\hline 1 & 0 & 0 & 1 & 1 & 0.986 & 1 \\
\hline 1 & 1 & 0 & 0 & 1 & 0.983 & 2 \\
\hline 0 & 1 & 1 & 0 & 1 & 0.978 & 1 \\
\hline 1 & 1 & 1 & 0 & 1 & 0.976 & 3 \\
\hline 0 & 1 & 1 & 1 & 1 & 0.961 & 2 \\
\hline 1 & 0 & 1 & 1 & 1 & 0.961 & 3 \\
\hline 1 & 0 & 1 & 0 & 1 & 0.936 & 2 \\
\hline 0 & 1 & 1 & 0 & 0 & 0.927 & 2 \\
\hline 1 & 0 & 1 & 0 & 0 & 0.836 & 4 \\
\hline 0 & 0 & 0 & 0 & 0 & & 0 \\
\hline 0 & 0 & 0 & 0 & 1 & & 0 \\
\hline 0 & 0 & 0 & 1 & 0 & & 0 \\
\hline 0 & 0 & 1 & 0 & 0 & & 0 \\
\hline 0 & 0 & 1 & 0 & 1 & & 0 \\
\hline 0 & 0 & 1 & 1 & 0 & & 0 \\
\hline 0 & 1 & 0 & 0 & 0 & & 0 \\
\hline 0 & 1 & 0 & 0 & 1 & & 0 \\
\hline 0 & 1 & 0 & 1 & 0 & & 0 \\
\hline 0 & 1 & 0 & 1 & 1 & & 0 \\
\hline 0 & 1 & 1 & 1 & 0 & & 0 \\
\hline 1 & 0 & 0 & 0 & 0 & & 0 \\
\hline 1 & 0 & 0 & 0 & 1 & & 0 \\
\hline 1 & 0 & 1 & 1 & 0 & & 0 \\
\hline 1 & 1 & 0 & 0 & 0 & & 0 \\
\hline 1 & 1 & 1 & 0 & 0 & & 0 \\
\hline 1 & 1 & 1 & 1 & 0 & & 0 \\
\hline
\end{tabular}

Table 8 Necessity check for single conditions

Necessity check for single conditions

\begin{tabular}{llll}
\hline Condition & Cons. Nec & Cov. Nec & RoN \\
\hline Congruence in governance structure & 0.681 & 0.775 & 0.656 \\
Congruence in administrative processes & 0.666 & 0.870 & 0.830 \\
Congruence in accountability processes & 0.556 & 0.831 & 0.838 \\
Receipt of expected resources & 0.645 & 0.969 & 0.966 \\
Receipt of unexpected resources & 0.688 & 0.955 & 0.943 \\
\hline
\end{tabular}

Supplementary information The online version of this article (https:// doi.org/10.1007/s10551-020-04714-y) contains supplementary material, which is available to authorized users.
Funding Open Access funding enabled and organized by Projekt DEAL. 


\section{Compliance with Ethical Standards}

Conflict of interest The authors herewith declare that our submission is compliant with ethical standards and that there is no conflict of interest.

Open Access This article is licensed under a Creative Commons Attribution 4.0 International License, which permits use, sharing, adaptation, distribution and reproduction in any medium or format, as long as you give appropriate credit to the original author(s) and the source, provide a link to the Creative Commons licence, and indicate if changes were made. The images or other third party material in this article are included in the article's Creative Commons licence, unless indicated otherwise in a credit line to the material. If material is not included in the article's Creative Commons licence and your intended use is not permitted by statutory regulation or exceeds the permitted use, you will need to obtain permission directly from the copyright holder. To view a copy of this licence, visit http://creativecommons.org/licenses/by/4.0/.

\section{References}

Ashraf, N., Ahmadsimab, A., \& Pinske, J. (2017). From animosity to affinity: The interplay of competing logics and interdependence in cross-sector partnerships. Journal of Management Studies, 54, 793-821.

Austin, J. E. (2000). Strategic collaboration between nonprofits and business. Nonprofit and Voluntary Sector Quarterly, 29, 69-97.

Austin, J. E. (2010). From organization to organization: On creating value. Journal of Business Ethics, 94, 13-15.

Austin, J. E., Gutierrez, R., Ogliastri, E., \& Ezequiel, R. (2007). Capitalizing on convergence. Stanford Social Innovation Review, 5, 24-31.

Austin, J. E., \& Seitanidi, M. M. (2012a). Collaborative value creation: A review of partnering between nonprofits and businesses. Part 1. Nonprofit and Voluntary Sector Quarterly, 41, 726-758.

Austin, J. E., \& Seitanidi, M. M. (2012b). Collaborative value creation: A review of partnering between nonprofits and businesses. Part 2. Partnership processes and outcomes. Nonprofit and Voluntary Sector Quarterly, 41, 726-758.

Axelrod, R. (1984). The evolution of cooperation. London: Penguin.

Battilana, J., \& Dorado, S. (2010). Building sustainable hybrid organizations: The case of commercial microfinance organizations. Academy of Management Journal, 53, 1419-1440.

Berger, I., Cunningham, P., \& Drumwright, M. E. (2004). Social alliances: Company-nonprofit collaboration. California Management Review, 47, 58-90.

Berger, P. L., \& Luckmann, T. (1967). The social construction of reality. New York: Anchor Books.

Berg-Schlosser, D., De Meur, G., Rihoux, B., \& Ragin, C. C. (2009). Qualitative comparative analysis (QCA) as an approach. In B. Rihoux \& C. C. Ragin (Eds.), Configurational comparative methods: Qualitative comparative analysis $(Q C A)$ and related techniques (pp. 1-18). Los Angeles: Sage.

Blau, P. (1964). Exchange and power in social life. New York: Wiley.

Bryson, J. M., Crosby, B. C., \& Stone, M. M. (2006). The design and implementation of cross-sector collaborations: Propositions from the literature. Public Administration, 66, 44-55.

Bryson, J. M., Crosby, B. C., \& Stone, M. M. (2015). Developing and implementing cross-sector collaborations: Needed and challenging. Public Administration, 75, 647-663.

Bull, M., \& Ridley-Duff, R. (2019). Towards an appreciation of ethics in social enterprise business models. Journal of Business Ethics, $159,619-634$.
Clarke, A., \& Crane, A. (2018). Cross-sector partnerships for systemic change: Systematized literature review and agenda for further research. Journal of Business Ethics, 150, 303-313.

Clarke, A., \& Fuller, M. (2010). Collaborative strategic management: Strategy formulation and implementation by multi-organizational cross-sector social partnerships. Journal of Business Ethics, 94, 85-101.

Cloutier, C., \& Langley, A. (2017). Negotiating the moral aspects of purpose in single and cross-sector collaborations. Journal of Business Ethics, 141, 103-131.

Crilly, D., Zollo, M., \& Hansen, M. T. (2012). Faking it or muddling through? Understanding decoupling in response to stakeholder pressures. Academy of Management Journal, 55(6), 1429-1448.

Cropanzano, R., \& Mitchell, M. S. (2005). Social exchange theory: An interdisciplinary review. Journal of Management, 31, 874-900.

Cui, L., Fan, D., Liu, X., \& Li, Y. (2017). Where to seek strategic assets for competitive catch-up? A configurational study of emerging multinational enterprises expanding into foreign strategic factor markets. Organization Studies, 38, 1059-1983.

Den Hond, F., de Bakker, F. G. A., \& Doh, J. (2015). What prompts companies to collaborate with NGOs? Recent evidence from the Netherlands. Business \& Society, 54, 187-228.

Di Domenico, M., Tracey, P., \& Haugh, H. (2009). The dialectic of social exchange: Theorizing corporate-social enterprise collaboration. Organization Studies, 30, 887-907.

Dusa, A. (2019). QCA with R. New York, NY: Springer.

Ekeh, P. P. (1974). Social exchange theory. The two traditions. London: Heinemann.

Emirbayer, M. (1997). Manifesto for a relational sociology. American Journal of Sociology, 103, 281-317.

Fehr, E., \& Gächter, S. (2000). Fairness and retaliation: The economics of reciprocity. Journal of Economic Perspectives, 14, 159-181.

Fiol, C., \& O'Connor, E. (2002). When hot and cold collide in radical change processes: Lessons from community development. Organization Science, 13, 532-546.

Fiss, P. C. (2011). Building better causal theories: A fuzzy set approach to typologies in organization research. Academy of Management Journal, 54, 393-420.

Gaeta, G.L., Ghinoi, S., \& Silvestri, F. (in press). Exploring networking of third sector organizations: A case study based on the Quartieri Spagnoli neighbourhood in Naples (Italy). Voluntas, forthcoming.

Giddens, A. (1984). The constitution of society: Outline of the theory of structuration. Cambridge: Polity Press.

Giddens, A. (1991). Modernity and self-identity. Self and society in the late modern age. Stanford: Stanford University Press.

Göbel, M., Vogel, R., \& Weber, C. (2013). Management research on reciprocity: A review of the literature. Business Research, 6 , 34-53.

Googins, B., \& Rochlin, S. (2000). Creating the partnership society: Understanding the rhetoric and reality of cross-sectoral partnerships. Business and Society Review, 105, 127-144.

Gouldner, A. (1960). The norm of reciprocity: A preliminary statement. American Sociological Review, 25, 161-178.

Hahn, T., \& Pinkse, J. (2014). Private environmental governance through cross-sector partnerships: Tensions between competition and effectiveness. Organization and Environment, 27, 140-160.

Kenny, D., Kashy, D., \& Cook, W. (2006). Dyadic data analysis. New York: Cambridge University Press.

Kinge, J. (2014). Testing times: The development and sustainability of partnership relationships. International Journal of Human Resource Management, 25, 852-878.

Kivleniece, I., \& Quélin, B. (2012). Creating and capturing value in public-private ties: A private actor's perspective. Academy of Management Review, 37, 272-299. 
Koschmann, M., Kuhn, T., \& Pfarrer, M. (2012). A communicative framework of value in cross-sector partnerships. Academy of Management Review, 37, 332-358.

Langley, A. (1999). Strategies for theorizing from process data. Academy of Management, 24(4), 691-710.

Le Ber, M., \& Branzei, O. (2010a). (Re)forming strategic cross-sector partnerships. Relational processes of social innovation. Business and Society, 49, 140-172.

Le Ber, M., \& Branzei, O. (2010b). Value frame fusion in cross sector interactions. Journal of Business Ethics, 94, 163-195.

Lefroy, K., \& Tsarenko, Y. (2013). From receiving to achieving. The role of relationship and dependence for non-profit organizations in corporate partnerships. European Journal of Marketing, 47, $1641-1666$.

Lefroy, K., \& Tsarenko, Y. (2014). Dependence and effectiveness in the nonprofit-corporate alliance: The mediating effect of objectives achievement. Journal of Business Research, 67(9), 1959-1966.

Le Pennec, M., \& Raufflet, E. (2016). Value creation in inter-organizational collaboration: An empirical case study. Journal of Business Ethics, 148, 817-834.

Levi-Strauss, C. (1969). The elementary structures of kinship. Boston: Beacon Press.

Lioukas, C., \& Reuer, J. (2015). Isolating trust outcomes from exchange relationships: Social exchange and learning benefits of prior ties in alliances. Academy of Management Journal, 58, 1826-1847.

Luckmann, B., \& Luckmann, T. (1979). Wissen und vorurteil. Hagen: Fernuniv.

Malinowski, B. (1922). Argonauts of the Western Pacific: An account of native enterprise and adventure in the archipelagos of Melanesian New Guinea. London: Routledge and Sons.

Mauss, M. (1990). The gift: The form and reason for exchange in archaic societies. New York: Norton.

Meyer, J., \& Rowan, B. (1977). Institutionalized organizations: Formal structure as myth and ceremony. American Journal of Sociology, 83, 340-363.

Millar, C., Choi, C., \& Chen, J. (2004). Global strategic partnerships between MNEs and NGOs: Drivers of change and ethical issues. Business and Society Review, 109, 395-414.

Min, J. (2017). Effects of the use of social network sites on task performance: Toward a sustainable performance in a distracting work environment. Sustainability (Switzerland), 9, 2270.

Montgomery, A., Dacin, P., \& Dacin, M. (2012). Collective social entrepreneurship: Collaboratively shaping social good. Journal of Business Ethics, 111, 375-388.

Muñoz, P., \& Dimov, D. (2015). The call of the whole in understanding the development of sustainable ventures. Journal of Business Venturing, 30, 632-654.

Muñoz, P., \& Kibler, E. (2015). Institutional complexity and social entrepreneurship: A fuzzy-set approach. Journal of Business Research, 69, 1314-1318.

Murphy, M., \& Arenas, D. (2010). Through indigenous lenses: Crosssector collaborations with fringe stakeholders. Journal of Business Ethics, 94, 103-121.

Murphy, M., Arenas, D., \& Batista, J. (2015). Value creation in crosssector collaborations: The roles of experience and alignment. Journal of Business Ethics, 130, 145-162.

Murphy, M., Perrot, P., \& Rivera-Santos, M. (2012). New perspectives on learning and innovation in cross-sector collaborations. Journal of Business Research, 65, 1700-1709.

Nelson, J., \& Zadek, S. (2011). Partnership alchemy. New social partnerships in Europe. The Copenhagen Centre. Retrieved from www.copenhagencentre.org.

Nicholls, A., \& Huybrechts, B. (2016). Sustaining inter-organizational relationships across institutional logics and power asymmetries: The case of fair trade. Journal of Business Ethics, 135, 699-714.
O’Mahony, S., \& Bechky, B. A. (2008). Boundary organizations: Enabling collaboration among unexpected allies. Administrative Science Quarterly, 53(3), 422-459.

Ott, U. F., Williams, D., Saker, J., \& Staley, L. (2019). A configurational analysis of the termination scenarios of international joint ventures: All is well that ends well. Journal of Innovation \& Knowledge, 4, 202-145.

Parmigiani, A., \& Rivera-Santos, M. (2011). Clearing a path through the forest: A meta-review of interorganizational relationships. Journal of Management, 37, 1108-1136.

Plowman, D., Baker, L., Beck, T., Kulkarni, M., Solansky, S., \& Travis, D. (2007). Radical change accidentally: The emergence and amplification of small change. Academy of Management Journal, 50, 515-543.

Provan, K., Fish, A., \& Sydow, J. (2007). Interorganizational networks at the network level: A review of the empirical literature on whole networks. Journal of Management, 33, 479-516.

Provan, K., \& Milward, H. (2001). Do networks really work? A framework for evaluating public-sector organizational networks? Public Administration Review, 61, 414-423.

Ragin, C. C. (1987). The comparative method: Moving beyond qualitative and quantitative strategies. Berkeley/Los Angeles/London: University of California Press.

Ragin, C. C. (2008). Redesigning social inquiry. Fuzzy sets and beyond. Chicago: University of Chicago Press.

Ragin, C. C., \& Fiss, P. (2008). Net effects analysis versus configurational analysis: An empirical demonstration. In C. C. Ragin (Ed.), Redesigning social inquiry: Fuzzy sets and beyond (pp. 190-212). Chicago: University of Chicago Press.

Reckwitz, A. (2002). Toward a theory of social practices: A development in culturalist theorizing. European Journal of Social Theory, 5, 243-263.

Rein, M., \& Stott, L. (2009). Working together: Critical perspectives on six cross-sector partnerships. Journal of Business Ethics, 90, $79-89$.

Rivera-Santos, M., \& Rufin, C. (2010). Odd couples: Understanding the governance of firm-NGO alliances. Journal of Business Ethics, 94, 55-70.

Rondinelli, D. A., \& London, T. (2003). How corporations and environmental groups collaborate: Assessing cross-sector alliances and collaborations. Academy of Management Perspectives, 17, 61-76.

Rueede, D., \& Kreutzer, K. (2015). Legitimation work within a crosssector social partnership. Journal of Business Ethics, 128, 39-58.

Sahlins, M. D. (1972). Stone age economics. New York, NY: Gruyter.

Sahlins, M. (1996). Sociology of primitive exchange. In A. E. Komter (Ed.), The gift: An interdisciplinary perspective (pp. 26-38). Amsterdam: Amsterdam University Press.

Sahlins, M. D. (2004). On the sociology of primitive exchange. In M. Banton (Ed.), The relevance of models for social anthropology (pp. 139-237). London: Routledge.

Sakarya, S., Bodur, M., Yildirim-Öktem, O., \& Selekler-Göksen, N. (2012). Social alliances: Business social enterprise collaboration for social transformation. Journal of Business Research, 65, $1710-1720$.

Schiller, R. S., \& Almog-Bar, M. (2013). Revisiting collaborations between nonprofits and businesses: An NPO-centric view and typology. Nonprofit and Voluntary Sector Quarterly, 42, 942-962.

Schneider, C. Q., \& Wagemann, C. (2012). Set-theoretic methods for the social sciences. A guide to qualitative comparative analysis. Cambridge: Cambridge University Press.

Schneider, C. Q., \& Rohling, I. (2013). Combining QCA and process tracing in set-theoretic multi-method research. Sociological Methods \& Research, 42(4), 559-597. 
Schütz, A. (1967). Collected papers 1: The problem of social reality. The Hague: Nijhoff.

Schütz, A. (1960). Der sinnhafte aufbau der sozialen welt. Eine einleitung in die verstehende soziologie. Springer-Verlag: Wien.

Seitanidi, M. M. (2007). Intangible economy? How can investors deliver change in business? Lessons from non-profit-business partnerships. Management Decision, 45, 853-865.

Seitanidi, M. M., \& Crane, A. (2009). Implementing CSR through partnerships: Understanding the selection, design and institutionalization of non-profit-business partnerships. Journal of Business Ethics, 85, 413-429.

Seitanidi, M. M., \& Crane, A. (Eds.). (2014). Responsible business and social partnerships: A research handbook. London: Routledge.

Seitanidi, M. M., Koufopoulos, D. N., \& Palmer, P. (2010). Partnership formation for change: Indicators for transformative potential in cross sector social partnerships. Journal of Business Ethics, 94, 139-161.

Selsky, J. W., \& Parker, B. (2005). Cross-sector partnerships to address social issues: Challenges to theory and practice. Journal of Management, 31, 849-873.

Selsky, J. W., \& Parker, B. (2010). Platforms for cross-sector social partnerships: Prospective sensemaking devices for social benefit. Journal of Business Ethics, 94, 21-37.

Shumate, M., Fu, J. S., \& Cooper, K. R. (2018). Does cross-sector collaboration lead to higher non-profit capacity? Journal of Business Ethics, 150, 385-399.

Suárez, D. F., \& Esparza, N. (2017). Institutional change and management of public-nonprofit partnerships. The American Review of Public Administration, 47, 648-660.

Tambling, R. B., Johnson, S. K., \& Johnson, L. N. (2011). Analyzing dyadic data from small samples: A pooled regression actorpartner interdependence model approach. Counselling Outcome Research and Evaluation, 2, 101-114.

Van Tulder, R., \& Keen, N. (2018). Capturing collaborative challenges: Designing complexity-sensitive theories of change for crosssector partnerships. Journal of Business Ethics, 150, 315-332.
Vurro, C., Dacin, M. T., \& Perrini, F. (2010). Institutional antecedents of partnering for social change: How institutional logics shape cross-sector social partnerships. Journal of Business Ethics, 94, $39-53$.

Waddock, S. A. (1989). Understanding social partnerships: An evolutionary model of partnership organizations. Administration \& Society, 21(1), 78-100.

Weber, C., \& Göbel, M. (2006). Economic exchange reciprocity or social obligation reciprocity? A grounded theory approach to exchange modalities of interorganisational relations. Venture Capital-An International Journal of Entrepreneurial Finance, 8, 303-330.

Weber, C., \& Göbel, M. (2010). Reciprocity as means of interorganizational governance - A multi-case analysis of exchange systems. Scandinavian Journal of Management, 26, 134-150.

Weber, C., \& Weber, B. (2011). Exploring the antecedents of social liabilities in CVC-triads - a dynamic social network perspective. Journal of Business Venturing, 26, 255-272.

Weber, C., Weidner, K., Kröger, A., \& Wallace, J. (2017). Social value creation in inter-organizational collaborations in the not-forprofit sector - Give and take from a dyadic perspective. Journal of Management Studies, 54, 929-956.

Weidner, K., Weber, C., \& Göbel, M. (2016). You scratch my back and I scratch yours: How social enterprises and their key partners legitimize each other through their relationship. Business and Society, 53, 493-532.

Westley, F., \& Vredenburg, H. (1991). Strategic bridging: The collaboration between environmentalists and business in the marketing of green products. Journal of Applied Behavioural Science, 27, 65-90.

Yunus, M., Moingeon, B., \& Lehman-Ortega, L. (2010). Building social business models: Lessons from the Grameen experience. Long Range Planning, 43, 308-325.

Publisher's Note Springer Nature remains neutral with regard to jurisdictional claims in published maps and institutional affiliations. 